\title{
Structural Revision of Lydiamycin A by Reinvestigation of the Stereochemistry
}

Sunghoon Hwang, ${ }^{\dagger}$ Daniel Shin, ${ }^{\dagger}$ Tae Ho Kim,,$^{\S}$ Joon Soo An, ${ }^{\dagger}$ Shin-Il Jo, ${ }^{\ddagger}$ Jichan Jang, Suckchang Hong," Jongheon Shin, ${ }^{\dagger}$ and Dong-Chan $\mathrm{Oh}^{*}{ }^{+}$

†Natural Products Research Institute, College of Pharmacy, Seoul National University, Seoul 08826, Republic of Korea

‡Welfare Division, Seoul Zoo, Seoul Grand Park, Gwacheon, Gyeonggi 13829, Republic of Korea $\S$ Molecular Mechanism of Antibiotics, Division of Life Science, Research Institute of Life Science, Gyeongsang National University, Jinju, Gyeongnam 52828, Republic of Korea

"Research Institute of Pharmaceutical Sciences, College of Pharmacy, Seoul National University, Seoul 08826, Republic of Korea

Correspondence to:

Prof. Dong-Chan Oh

Natural Products Research Institute,

College of Pharmacy,

Seoul National University, 1 Gwanak-ro, Gwanak-gu,

Seoul 08826, Republic of Korea

TEL: 82-2-880-2491; FAX: 82-2-762-8322; E-mail: dongchanoh@snu.ac.kr 


\section{Table of Contents}

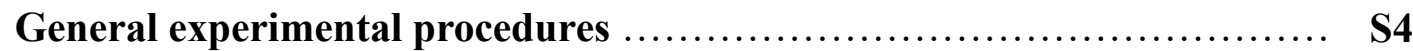

Collection and Phylogenetic Analysis ............................. S4

Cultivation and extraction .......................................... S4

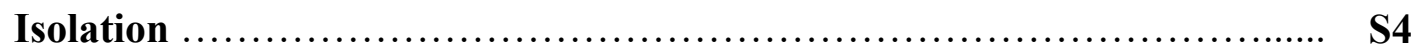

Table S1. NMR spectral data for lydiamycin A (1) in DMSO- $d_{6}$ and $\mathrm{CDCl}_{3} \ldots$ S5-6

Figure S1. COSY and key HMBC correlations of lydiamycin A (1) .......... S7

Figure S2. ${ }^{1} \mathrm{H}$ NMR spectrum of lydiamycin A (1) in DMSO- $d_{6} \ldots \ldots \ldots \ldots \ldots . \quad$ S8

Figure S3. ${ }^{13} \mathrm{C}$ NMR spectrum of lydiamycin A (1) in DMSO- $d_{6} \ldots \ldots \ldots \ldots . \quad$ S8

Figure S4. COSY spectrum of lydiamycin A (1) in DMSO- $d_{6} \ldots \ldots \ldots \ldots \ldots \ldots$ S9

Figure S5. HSQC spectrum of lydiamycin A (1) in DMSO- $d_{6} \ldots \ldots \ldots \ldots \ldots . . . \ldots 9$

Figure S6. HMBC spectrum of lydiamycin A (1) in DMSO- $d_{6} \ldots \ldots \ldots \ldots \ldots . \quad$ S10

Figure S7. ROESY spectrum of lydiamycin A (1) in DMSO- $d_{6} \ldots \ldots \ldots \ldots \ldots . \quad \mathbf{S 1 0}$

Figure S8. ${ }^{1} \mathrm{H}$ NMR spectrum of lydiamycin $\mathrm{A}(\mathbf{1})$ in $\mathrm{CDCl}_{3} \ldots \ldots \ldots \ldots \ldots \ldots . \mathbf{S 1 1}$

Figure S9. ${ }^{13} \mathrm{C}$ NMR spectrum of lydiamycin $\mathrm{A}(\mathbf{1})$ in $\mathrm{CDCl}_{3} \ldots \ldots \ldots \ldots \ldots \ldots . \mathbf{S 1 1}$

Figure S10. COSY spectrum of lydiamycin $\mathrm{A}(\mathbf{1})$ in $\mathrm{CDCl}_{3} \ldots \ldots \ldots \ldots \ldots \ldots . \mathbf{S 1 2}$

Figure S11. HSQC spectrum of lydiamycin $\mathrm{A}(\mathbf{1})$ in $\mathrm{CDCl}_{3} \ldots \ldots \ldots \ldots \ldots \ldots . \mathbf{S 1 2}$

Figure S12. HMBC spectrum of lydiamycin $\mathrm{A}(\mathbf{1})$ in $\mathrm{CDCl}_{3} \ldots \ldots \ldots \ldots \ldots \ldots . \mathbf{S 1 3}$

Figure S13. NOESY spectrum of lydiamycin $\mathrm{A}(\mathbf{1})$ in $\mathrm{CDCl}_{3} \ldots \ldots \ldots \ldots \ldots \ldots . \mathbf{S 1 3}$

Determination of the absolute configurations of the amino acid units S14

Table S2. LC/MS analysis of L- and D-FDAA derivatives of lydiamycin A (1) . S14

Figure S14. Computational 3D models of $2 S$ and $2 R$ of lydiamycin A (1) ...... S14

Analysis of the structure of the FDAA adducts of piperazic acid ..... S15

Figure S15. ${ }^{1} \mathrm{H}$ NMR spectrum of reaction product of $S$-piperazic acid with L-

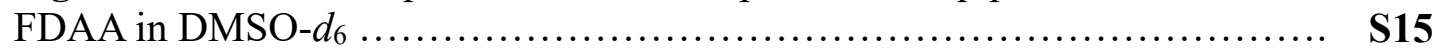

Figure S16. HSQC spectrum of reaction product of $S$-piperazic acid with L-

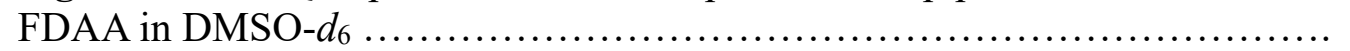

Figure S17. COSY spectrum of reaction product of $S$-piperazic acid with L-

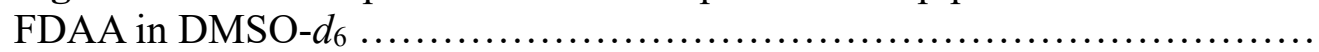

Figure S18. ROESY spectrum of reaction product of $S$-piperazic acid with L-

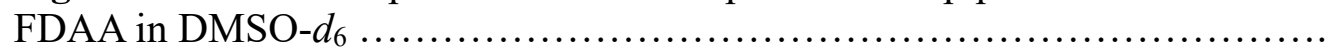
Figure S19. ${ }^{1} \mathrm{H}$ NMR spectrum of reaction product of $S$-piperazic acid with DFDAA in DMSO- $d_{6}$

Figure S20. HSQC spectrum of reaction product of $S$-piperazic acid with DFDAA in DMSO- $d_{6}$

Figure S21. COSY spectrum of reaction product of $S$-piperazic acid with DFDAA in DMSO- $d_{6}$

Figure S22. ROESY spectrum of reaction product of $S$-piperazic acid with DFDAA in DMSO- $d_{6}$

Figure S23. Computational 3D models of reaction product of $S$-piperazic acid with L- and D-FDAA reagents .... 
Figure S24. LC/MS analysis of the FDAA adducts of the reduction product of

Table S3. LC/MS analysis of L- and D-FDAA derivatives of the reduction product of $\mathbf{1}$

Conformational search and DP4 analysis of lydiamycin A (1)

Figure S25. Result of DP4 calculation from the simulated models of two possible diastereomers $(19 S, 19 R)$

Table S4. The major conformers of lydiamycin A (1) identified by conformational searches in MMFF94 force field using the macromodel

Table S5. Experimental and calculated chemical shift values of lydiamycin A (1)

PGME derivatization of lydiamycin A (1)

Figure S26. ${ }^{1} \mathrm{H}$ NMR Spectrum of $S$-PGME derivatized lydiamycin A (1a) in DMSO- $d_{6}$

Figure S27. COSY Spectrum of $S$-PGME derivatized lydiamycin A (1a) in DMSO- $d_{6}$ ..

Figure S28. ${ }^{1} \mathrm{H}$ NMR Spectrum of $R$-PGME derivatized lydiamycin A (1b) in

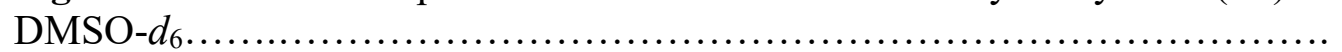
Figure S29. COSY Spectrum of $R$-PGME derivatized lydiamycin A (1b) in

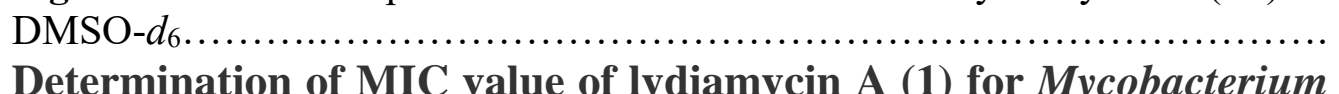
tuberculosis by resazurin microtitre assay (REMA) Reference S30 S30 


\section{General experimental procedures}

Optical rotations were measured by a JASCO P-200 polarimeter (sodium light source, JASCO, Easton, PA, USA) with a $1-\mathrm{cm}$ cell. UV spectra were acquired on a Chirascan plus Applied Photophysics spectrophotometer. IR spectra were obtained using a Thermo NICOLET iS10 spectrometer (Thermo, Madison, CT, USA). ${ }^{1} \mathrm{H},{ }^{13} \mathrm{C}$, and 2D nuclear magnetic resonance (NMR) spectra were recorded on a Bruker Avance $800 \mathrm{MHz}$ spectrometer (Bruker, Billerica, MA, USA) at the Research Institute of Pharmaceutical Sciences at Seoul National University. Electrospray ionization (ESI) low-resolution LC/MS data were recorded using an Agilent Technologies 6130 quadrupole mass spectrometer (Agilent Technologies, Santa Clara, CA, USA) coupled with an Agilent Technologies 1200 series highperformance liquid chromatography (HPLC) instrument using a reversed-phase C18 column (Phenomenex Luna, $100 \times 4.6 \mathrm{~mm}$ ). High-resolution fast atom bombardment (HR-FAB) mass spectra were recorded using a Jeol JMS-600 W high-resolution mass spectrometer (Jeol, München, Germany) at the National Center for Inter-university Research Facilities at Seoul National University.

\section{Collection and phylogenetic analysis}

The mealworm beetle-associated actinomycete strain GG23 was isolated from the gut of a Tenebrio molitor specimen bred and collected from Seoul Grand Park. It was identified as a Streptomyces sp. that is phylogenetically closest to Streptomyces cacaoi (GenBank accession number NZ_MUBL01000000) based on 16S rRNA gene sequence analysis (GenBank accession number MT033037).

\section{Cultivation and extraction}

The GG23 strain was cultured in $50 \mathrm{~mL}$ of modified $\mathrm{K}$ medium ( $4 \mathrm{~g}$ of yeast extract, $5 \mathrm{~g}$ of malt extract, $5 \mathrm{~g}$ of soytone, $5 \mathrm{~g}$ of soluble starch, $5 \mathrm{~g}$ of mannitol, $2 \mathrm{~g}$ of glucose, and $6 \mathrm{~g}$ of glycerol in $1 \mathrm{~L}$ of distilled water) in a $125-\mathrm{mL}$ Erlenmeyer flask. After cultivation for 3 days on a rotary shaker at $200 \mathrm{rpm}$ at $30^{\circ} \mathrm{C}, 5 \mathrm{~mL}$ of the culture medium was inoculated in $200 \mathrm{~mL}$ of modified $\mathrm{K}$ medium in a $500-\mathrm{mL}$ Erlenmeyer flask. After cultivation for 3 days under the same conditions, $10 \mathrm{~mL}$ of the culture medium was inoculated in $1 \mathrm{~L}$ of modified $\mathrm{K}$ medium in 2.8 - $\mathrm{L}$ Fernbach flasks $(60 \mathrm{ea} \times 1 \mathrm{~L}$, total volume $60 \mathrm{~L})$ for 4 days at $170 \mathrm{rpm}$ at $30^{\circ} \mathrm{C}$. Sixty liters of GG23 culture medium was extracted with $120 \mathrm{~L}$ of ethyl acetate. The ethyl acetate and water fractions were separated, and the remaining water in the ethyl acetate was removed with anhydrous sodium sulfate. The ethyl acetate was removed by a rotary evaporator, and the extract was dried in vacuo to yield $25 \mathrm{~g}$ of organic material.

\section{Isolation}

The crude extract was injected directly onto a preparative reversed-phase HPLC column $\left(\mathrm{C}_{18}\right.$ Luna 10 $\mu \mathrm{m} \mathrm{C}_{18}(2) 250 \times 21.2 \mathrm{~mm}, 10 \mathrm{~mL} / \mathrm{min}$, detection: $\mathrm{UV}$ at $210 \mathrm{~nm}$ ) and separated using a gradient solvent system from $30 \%$ to $70 \% \mathrm{CH}_{3} \mathrm{CN} /$ water over $40 \mathrm{~min}$. Lydiamycin $\mathrm{A}(\mathbf{1})$ was isolated at a retention time of $31 \mathrm{~min}(10 \mathrm{mg})$. Compound 1 was further purified on a CN HPLC column (YMC CN, $250 \times 10 \mathrm{~mm}$, S-5 $\mu \mathrm{m}, 12 \mathrm{~nm})$ using a gradient $\left(30 \% \mathrm{CH}_{3} \mathrm{CN} /\right.$ water to $70 \% \mathrm{CH}_{3} \mathrm{CN} /$ water over $40 \mathrm{~min}$, UV detection at $210 \mathrm{~nm}$, flow rate: $2 \mathrm{~mL} / \mathrm{min}$ ) to yield $1\left(\mathrm{t}_{\mathrm{R}} 25 \mathrm{~min}, 7.7 \mathrm{mg}\right)$.

Lydiamycin A (1): white amorphous solid; $[\alpha]_{\mathrm{D}}^{20}-21\left(c 0.1, \mathrm{CHCl}_{3}\right)$; UV $(\mathrm{MeOH}) \lambda_{\max }(\log \varepsilon) 200$ (3.31) nm; IR (neat) $v_{\max } 3310,2941,2829,1407,1022,632 \mathrm{~cm}^{-1} ;{ }^{1} \mathrm{H},{ }^{13} \mathrm{C}$ and 2D-NMR $(800 \mathrm{MHz}$, DMSO- $d_{6}$ and $\mathrm{CDCl}_{3}$ ), see Table S1; HRMS (FAB) $m / z$ : $[\mathrm{M}+\mathrm{H}]^{+}$Calcd for $\mathrm{C}_{31} \mathrm{H}_{50} \mathrm{~N}_{7} \mathrm{O}_{9}, 664.3670$; Found 664.3666. 
Table S1. NMR spectral data for lydiamycin A (1) ${ }^{\mathrm{a}}$

\begin{tabular}{|c|c|c|c|c|c|c|}
\hline \multirow[b]{2}{*}{ No. } & \multicolumn{2}{|c|}{$1\left(\mathrm{DMSO}-d_{6}\right)$} & \multicolumn{2}{|c|}{$\mathbf{1}\left(\mathrm{CDCl}_{3}\right)$} & \multicolumn{2}{|c|}{$\mathbf{1}$ (originally reported) $^{\mathrm{c}}\left(\mathrm{CDCl}_{3}\right)$} \\
\hline & $\delta_{\mathrm{C}}$, mult. $^{\mathrm{b}}$ & $\delta_{\mathrm{H}}(J$ in $\mathrm{Hz})$ & $\delta_{\mathrm{C}}$, mult. $^{\mathrm{b}}$ & $\delta_{\mathrm{H}}(\mathrm{J}$ in $\mathrm{Hz})$ & $\delta_{\mathrm{C}}$, mult. $^{\mathrm{b}}$ & $\delta_{\mathrm{H}}(J$ in $\mathrm{Hz})$ \\
\hline 1 & $169.4, \mathrm{qC}$ & & $169.8, \mathrm{qC}$ & & $169.1, \mathrm{qC}$ & \\
\hline 2 & $50.6, \mathrm{CH}$ & $5.04, \mathrm{~m}$ & 52.7, $\mathrm{CH}$ & $5.30, \mathrm{~m}$ & 52.7, $\mathrm{CH}$ & $5.28, \mathrm{~m}$ \\
\hline 3 & $24.0, \mathrm{CH}_{2}$ & $2.10,1.68, \mathrm{~m}$ & $24.4, \mathrm{CH}_{2}$ & $2.38,1.77, \mathrm{~m}$ & $24.4, \mathrm{CH}_{2}$ & $2.35,1.77, \mathrm{~m}$ \\
\hline 4 & $21.1, \mathrm{CH}_{2}$ & $1.51,1.43, \mathrm{~m}$ & $21.4, \mathrm{CH}_{2}$ & $1.63,1.59, \mathrm{~m}$ & $21.4, \mathrm{CH}_{2}$ & $1.60, \mathrm{~m}$ \\
\hline 5 & $46.3, \mathrm{CH}_{2}$ & $3.02,2.62, \mathrm{~m}$ & $47.1, \mathrm{CH}_{2}$ & $\begin{array}{c}3.14, \mathrm{~m}, 2.77, \mathrm{qd}(12.0, \\
3.0)\end{array}$ & 47.1, $\mathrm{CH}_{2}$ & $\begin{array}{l}\text { 3.12, br d (13.5), 2.75, br } \\
\text { dq }(13.5,3.8)\end{array}$ \\
\hline $5-\mathrm{NH}$ & & $4.52, \mathrm{~d}(12.0)$ & & $4.32, \mathrm{~d}(12.0)$ & & 4.31, br d \\
\hline 6 & $172.0, \mathrm{qC}$ & & 174.3, qC & & 174.3, qC & \\
\hline 7 & $51.6, \mathrm{CH}$ & 4.37, qd $(9.0,7.0)$ & $50.5, \mathrm{CH}$ & 4.85, qd $(10.5,7.0)$ & $50.5, \mathrm{CH}$ & $4.83, \mathrm{qd}(10.5,7.25)$ \\
\hline 7-NH & & $7.93, \mathrm{~d}(9.0)$ & & 7.30, d (10.5) & & 7.27, d (10.5) \\
\hline 8 & $16.1, \mathrm{CH}_{3}$ & $1.37, \mathrm{~d}(7.5)$ & 18.3 & $1.44, \mathrm{~d}(7.0)$ & 18.2 & $1.43, \mathrm{~d}(7.25)$ \\
\hline 9 & 170.0, qC & & $169.0, \mathrm{qC}$ & & $169.3, \mathrm{qC}$ & \\
\hline 10 & $50.8, \mathrm{CH}$ & $4.29, \mathrm{~m}$ & $51.4, \mathrm{CH}$ & $4.35, \operatorname{td}(8.5,8.5)$ & $51.4, \mathrm{CH}$ & $4.33, \mathrm{~m}$ \\
\hline $10-\mathrm{NH}$ & & $8.19, \mathrm{~m}$ & & 7.46, d (8.5) & & $7.43, \mathrm{~d}(7.8)$ \\
\hline 11 & 37.6, $\mathrm{CH}_{2}$ & $1.55,1.44, \mathrm{~m}$ & $36.4, \mathrm{CH}_{2}$ & $1.78, \mathrm{~m}$ & 36.6, $\mathrm{CH}_{2}$ & $1.77, \mathrm{~m}$ \\
\hline 12 & $24.2, \mathrm{CH}$ & $1.45, \mathrm{~m}$ & 24.6, $\mathrm{CH}$ & $1.65, \mathrm{~m}$ & 24.6, CH & $1.63, \mathrm{~m}$ \\
\hline 13 & $22.7, \mathrm{CH}_{3}$ & $0.89, \mathrm{~d}(6.0)$ & $22.8, \mathrm{CH}_{3}$ & $0.93, \mathrm{~d}(6.5)$ & $22.7, \mathrm{CH}_{3}$ & $0.93, d(6.5)$ \\
\hline 14 & $21.9, \mathrm{CH}_{3}$ & $0.82, \mathrm{~d}(6.0)$ & $22.3, \mathrm{CH}_{3}$ & $0.88, \mathrm{~d}(6.5)$ & $22.2, \mathrm{CH}_{3}$ & $0.87, \mathrm{~d}(7.8)$ \\
\hline 15 & 170.3, qC & & 169.3, qC & & 169.7, qC & \\
\hline 16 & $52.7, \mathrm{CH}$ & $4.42, \operatorname{td}(9.0,7.0)$ & $50.6, \mathrm{CH}$ & $5.31, \mathrm{~m}$ & $50.7, \mathrm{CH}$ & $5.28, \mathrm{~m}$ \\
\hline $16-\mathrm{NH}$ & & $8.27, \mathrm{~m}$ & & $8.30, \mathrm{~d}(10.0)$ & & $8.25, \mathrm{~d}(9.85)$ \\
\hline 17 & $62.9, \mathrm{CH}_{2}$ & $4.61,3.81, \mathrm{dd}(10.0,7.0)$ & $68.3, \mathrm{CH}_{2}$ & $\begin{array}{c}4.77, \mathrm{dd}(11.5,4.5), 4.04, \mathrm{~d} \\
(11.5)\end{array}$ & $68.2, \mathrm{CH}_{2}$ & $\begin{array}{l}\text { 4.75, dd }(11.4,4.4), 4.03, \\
\text { br d }(11.4)\end{array}$ \\
\hline 18 & 169.6, qC & & 171.0, qC & & $170.9, \mathrm{qC}$ & \\
\hline 19 & $51.3, \mathrm{CH}$ & $4.95, \mathrm{~m}$ & $55.6, \mathrm{CH}$ & $4.67, \mathrm{t}(5.0)$ & $55.6, \mathrm{CH}$ & 4.65, br t (5.7) \\
\hline 20 & $18.8, \mathrm{CH}_{2}$ & $2.24,1.77, \mathrm{~m}$ & $19.4, \mathrm{CH}_{2}$ & $2.35,1.92, \mathrm{~m}$ & $19.3, \mathrm{CH}_{2}$ & $2.35,1.93, \mathrm{~m}$ \\
\hline
\end{tabular}




\begin{tabular}{|c|c|c|c|c|c|c|}
\hline 21 & $19.5, \mathrm{CH}_{2}$ & $2.15,1.84, \mathrm{~m}$ & 20.6, $\mathrm{CH}_{2}$ & $2.17,1.95, \mathrm{~m}$ & 20.6, $\mathrm{CH}_{2}$ & $2.15,1.92, \mathrm{~m}$ \\
\hline 22 & $141.8, \mathrm{CH}$ & $6.91, \mathrm{~d}(4.0)$ & $142.7, \mathrm{CH}$ & $6.92, \mathrm{~m}$ & $142.7, \mathrm{CH}$ & $6.90, \mathrm{br} \mathrm{s}$ \\
\hline 23 & 173.3, qC & & $175.9, \mathrm{qC}$ & & $175.9, \mathrm{qC}$ & \\
\hline 24 & $35.4, \mathrm{CH}_{2}$ & $2.53,2.28, \mathrm{~m}$ & 36.6, $\mathrm{CH}_{2}$ & $\begin{array}{c}\text { 3.32, dd }(17.0,12.0), 2.62 \text {, } \\
\text { dd }(17.0,5.5)\end{array}$ & $36.5, \mathrm{CH}_{2}$ & $\begin{array}{c}\text { 3.30, dd }(16.8,12.2), 2.60 \\
\text { dd }(16.8,5.3)\end{array}$ \\
\hline 25 & $36.4, \mathrm{CH}$ & $3.67, \mathrm{~m}$ & $46.0, \mathrm{CH}$ & $3.04, \mathrm{~m}$ & $46.0, \mathrm{CH}$ & $3.02, \mathrm{~m}$ \\
\hline 26 & $31.0, \mathrm{CH}_{2}$ & $1.54,1.30, \mathrm{~m}$ & 31.6, $\mathrm{CH}_{2}$ & $1.72,1.53, \mathrm{~m}$ & 31.6, $\mathrm{CH}_{2}$ & $1.71,1.52, \mathrm{~m}$ \\
\hline 27 & $31.2, \mathrm{CH}_{2}$ & $1.19, \mathrm{~m}$ & $26.9, \mathrm{CH}_{2}$ & $1.35,1.25, \mathrm{~m}$ & $26.8, \mathrm{CH}_{2}$ & $1.35,1.24, \mathrm{~m}$ \\
\hline 28 & 25.6, $\mathrm{CH}_{2}$ & $1.22, \mathrm{~m}$ & $31.5, \mathrm{CH}_{2}$ & $1.29,1.25, \mathrm{~m}$ & $31.5, \mathrm{CH}_{2}$ & $1.27-1.26, \mathrm{~m}$ \\
\hline 29 & $21.8, \mathrm{CH}_{2}$ & $1.23, \mathrm{~m}$ & 22.4, $\mathrm{CH}_{2}$ & $1.27, \mathrm{~m}$ & $22.4, \mathrm{CH}_{2}$ & $1.27-1.26, \mathrm{~m}$ \\
\hline 30 & $13.8, \mathrm{CH}_{3}$ & $0.83, \mathrm{t}(7.0)$ & $14.0, \mathrm{CH}_{3}$ & $0.86, \mathrm{t}(7.0)$ & 13.9, $\mathrm{CH}_{3}$ & $0.85, \mathrm{t}(6.5)$ \\
\hline 31 & 175.2, qC & & 177.3, qC & & 177.3, qC & \\
\hline $31-\mathrm{OH}$ & & $12.01, \mathrm{br} \mathrm{s}$ & & $11.37, \mathrm{br} \mathrm{s}$ & & - \\
\hline
\end{tabular}

${ }^{\mathrm{a}} 800 \mathrm{MHz}$ for ${ }^{1} \mathrm{H}$ NMR and $200 \mathrm{MHz}$ for ${ }^{13} \mathrm{C}$ NMR. ${ }^{b}$ Numbers of attached protons were determined by analysis of $2 \mathrm{D}$ spectra. ${ }^{c} 500 \mathrm{MHz}$ for ${ }^{1} \mathrm{H}$ NMR and $75.5 \mathrm{MHz}$ for ${ }^{13} \mathrm{C}$ NMR. 
Figure S1. COSY and key HMBC correlations of lydiamycin A (1).

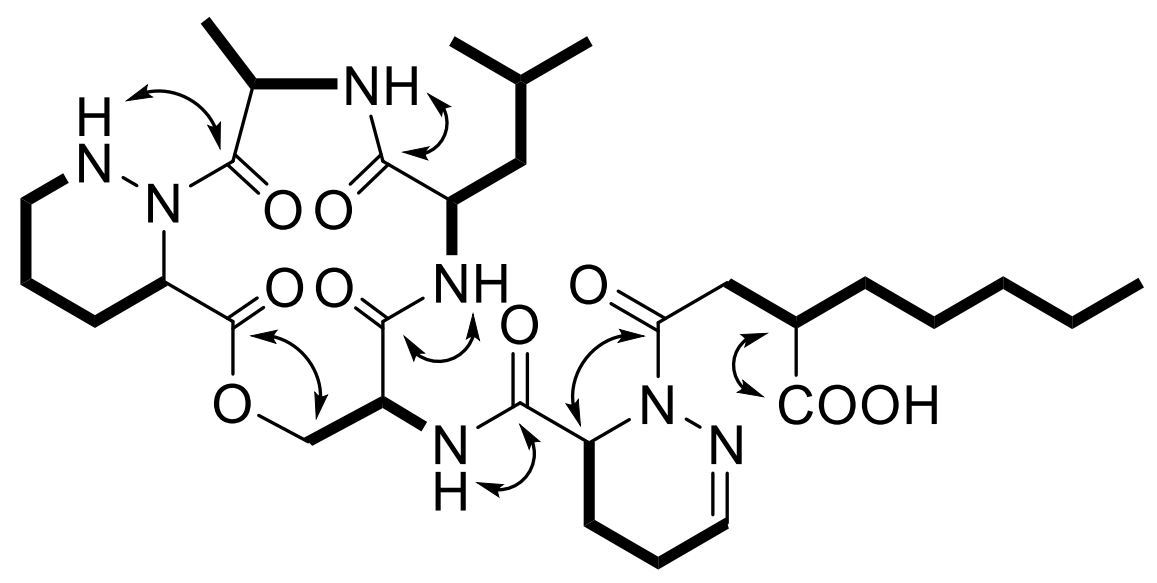

$$
\longleftrightarrow \text { HMBC }
$$


Figure S2. ${ }^{1} \mathrm{H}$ NMR spectrum of lydiamycin A (1) at $800 \mathrm{MHz}$ in DMSO- $d_{6}$.

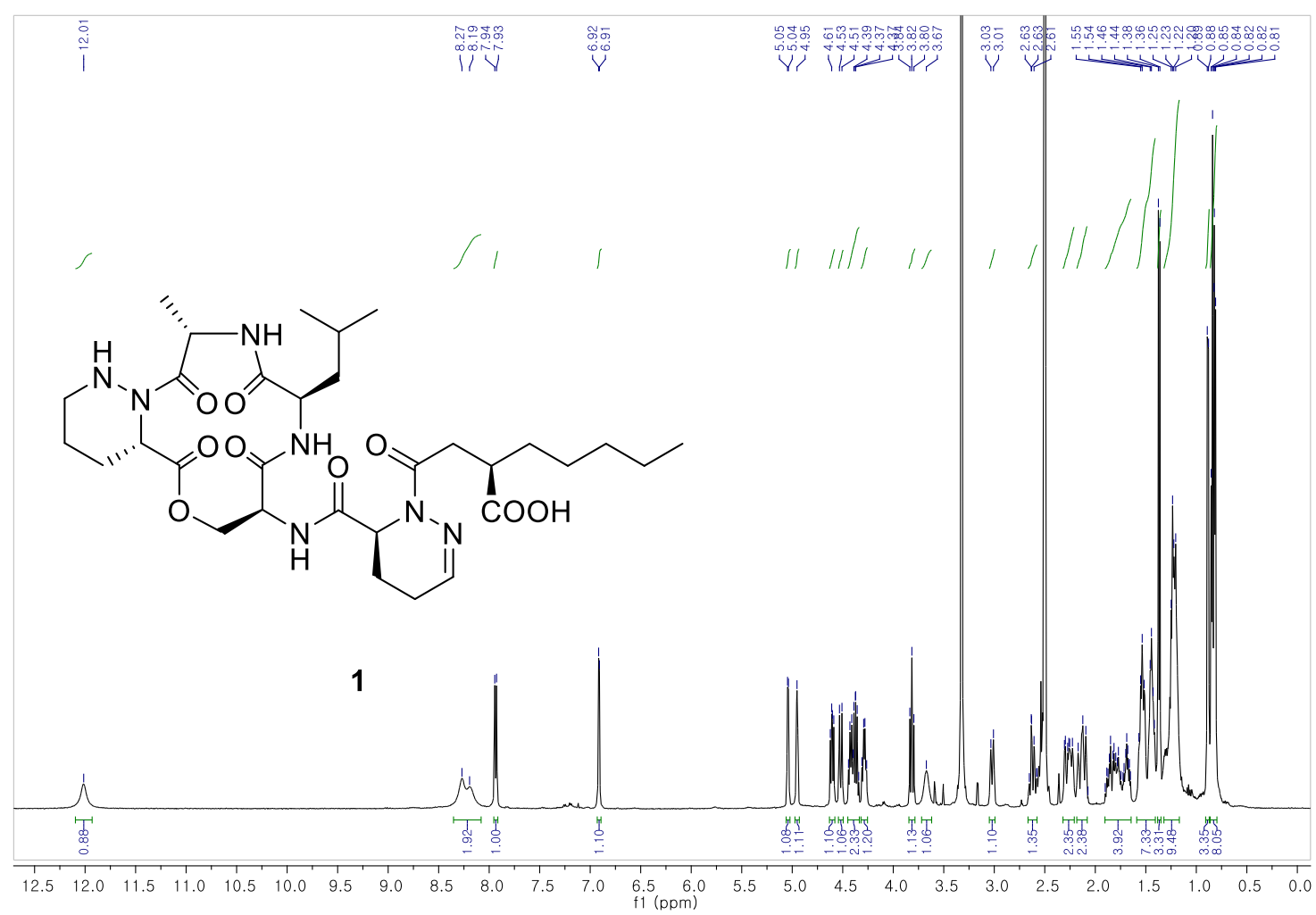

Figure S3. ${ }^{13} \mathrm{C}$ NMR spectrum of lydiamycin A (1) at $200 \mathrm{MHz}$ in DMSO- $d_{6}$.

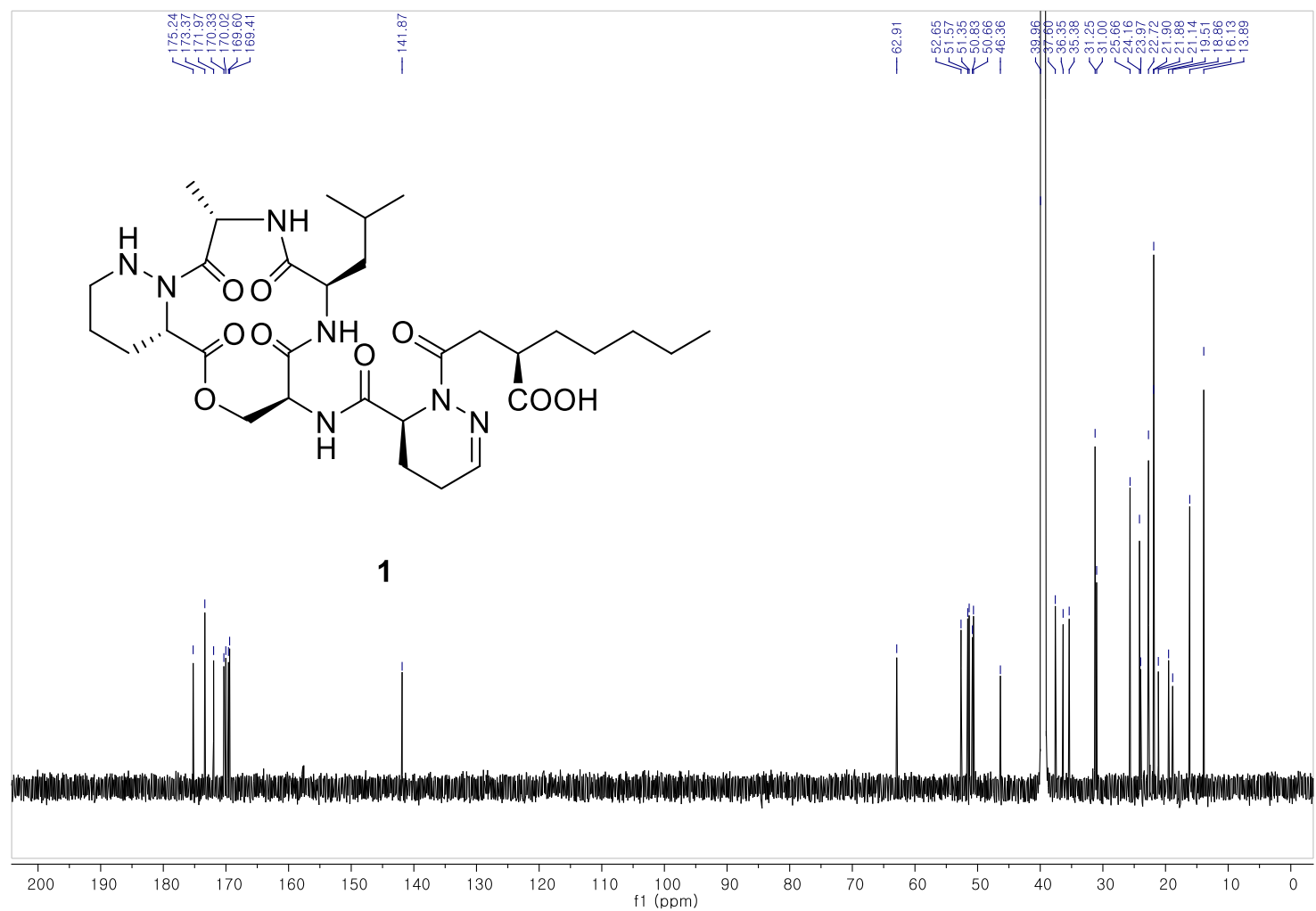


Figure S4. COSY spectrum of lydiamycin A (1) at $800 \mathrm{MHz}$ in DMSO- $d_{6}$.

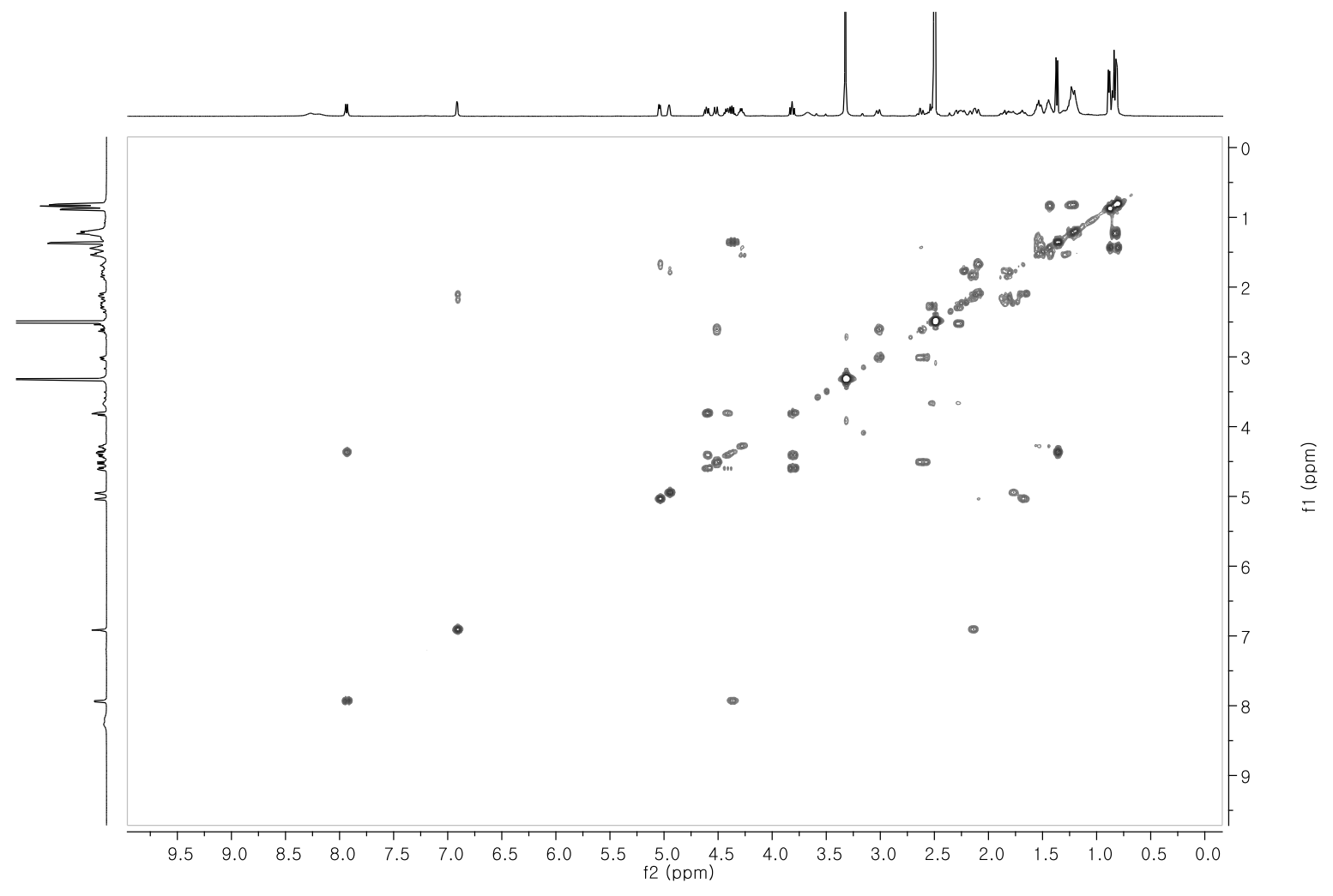

Figure S5. HSQC spectrum of lydiamycin A (1) at $800 \mathrm{MHz}$ in DMSO- $d_{6}$.

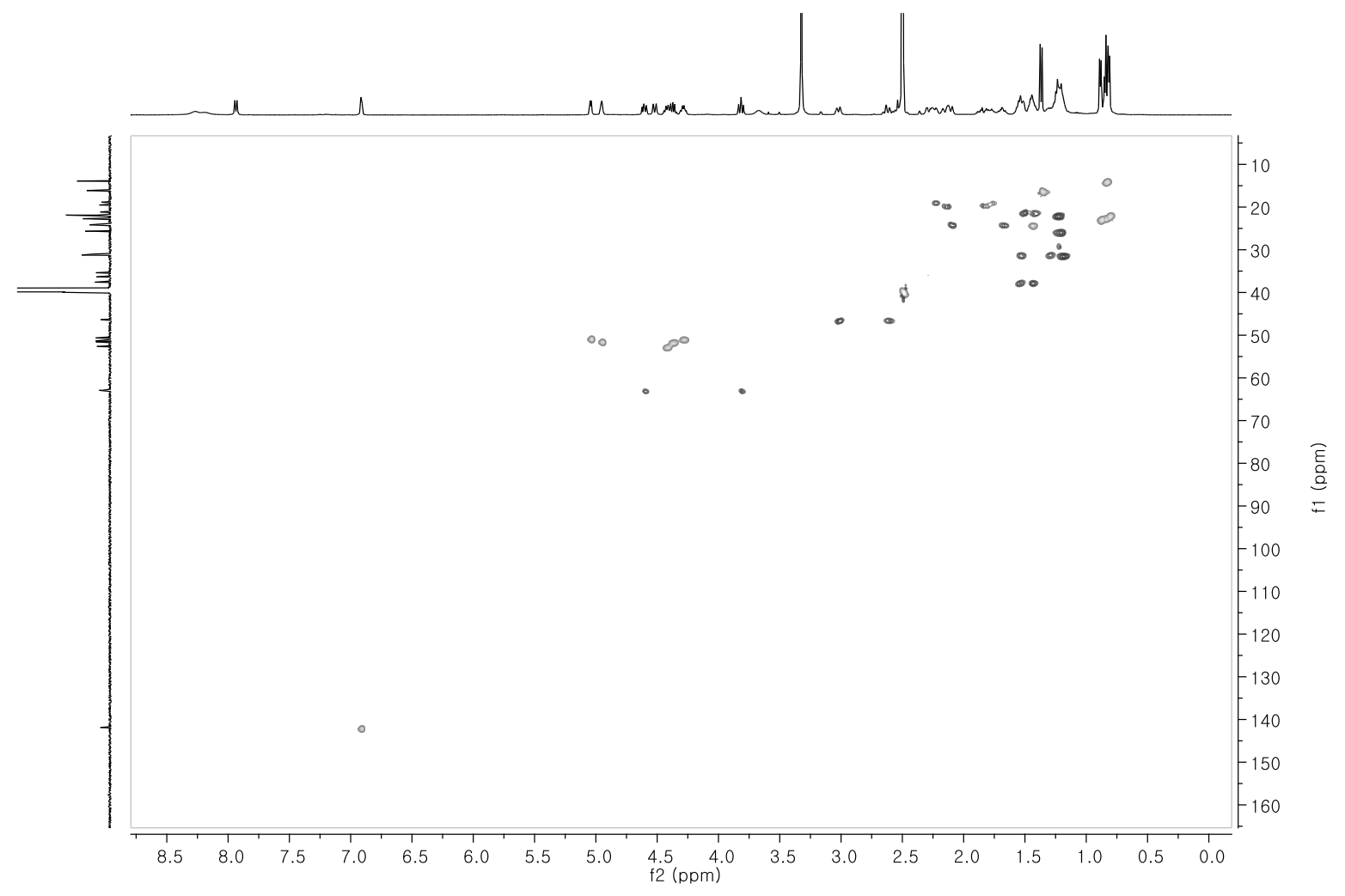


Figure S6. HMBC spectrum of lydiamycin A (1) at $800 \mathrm{MHz}$ in DMSO- $d_{6}$.

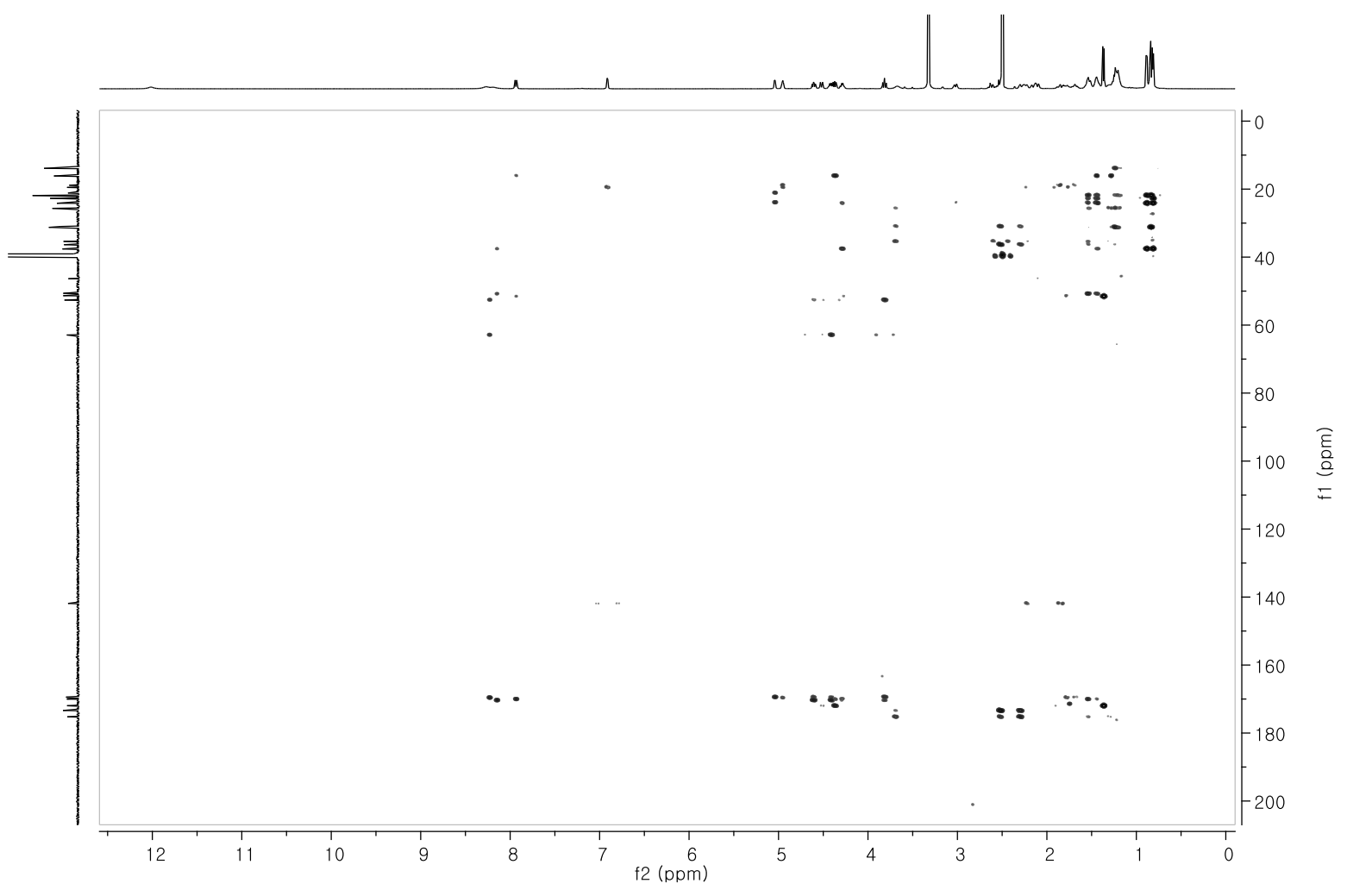

Figure S7. ROESY spectrum of lydiamycin A (1) at $800 \mathrm{MHz}$ in DMSO- $d_{6}$.

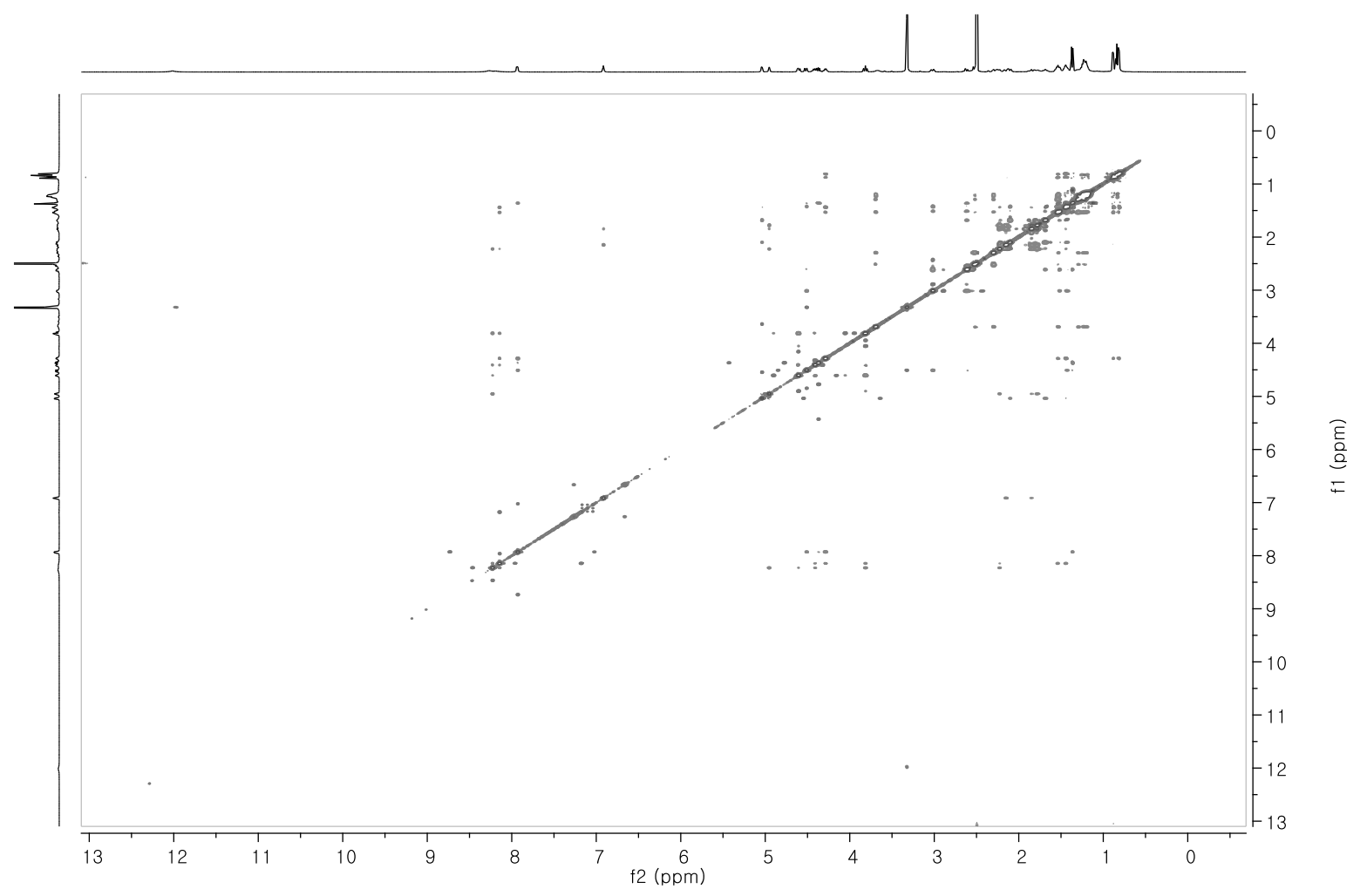


Figure S8. ${ }^{1} \mathrm{H}$ NMR spectrum of lydiamycin A (1) at $800 \mathrm{MHz}$ in $\mathrm{CDCl}_{3}$.

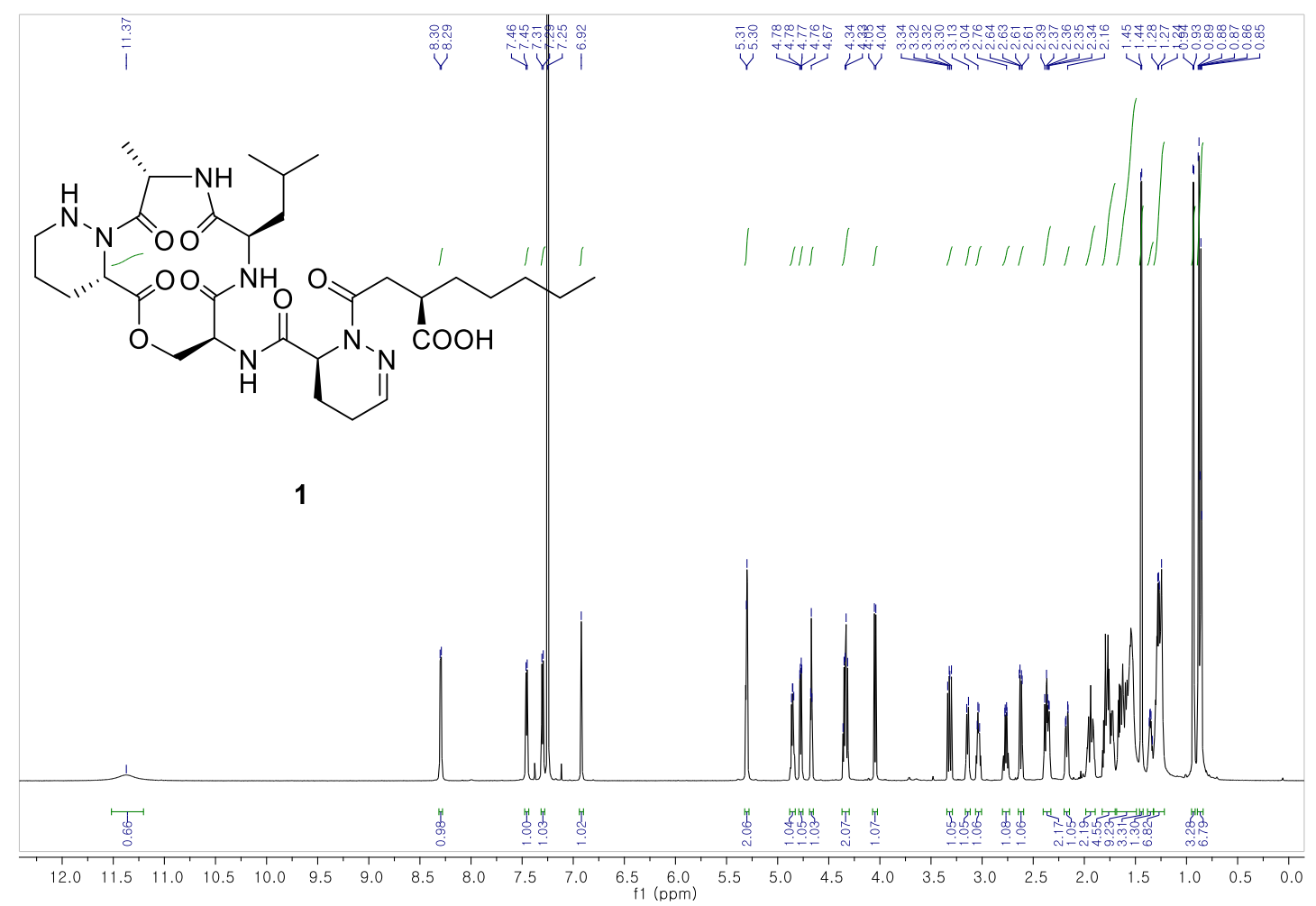

Figure S9. ${ }^{13} \mathrm{C}$ NMR spectrum of lydiamycin $\mathrm{A}(1)$ at $200 \mathrm{MHz}$ in $\mathrm{CDCl}_{3}$.

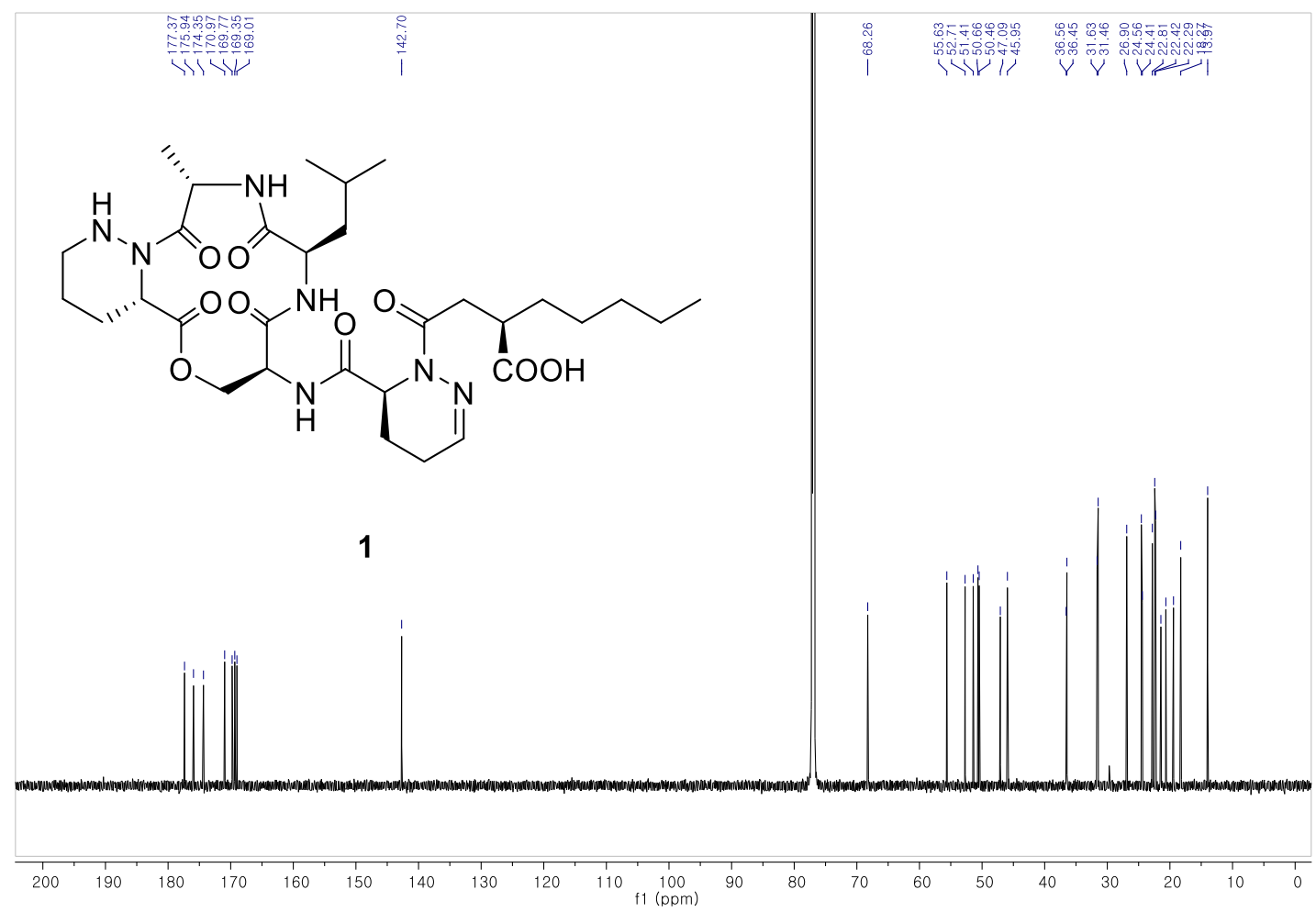


Figure S10. COSY spectrum of lydiamycin A (1) at $800 \mathrm{MHz}$ in $\mathrm{CDCl}_{3}$.

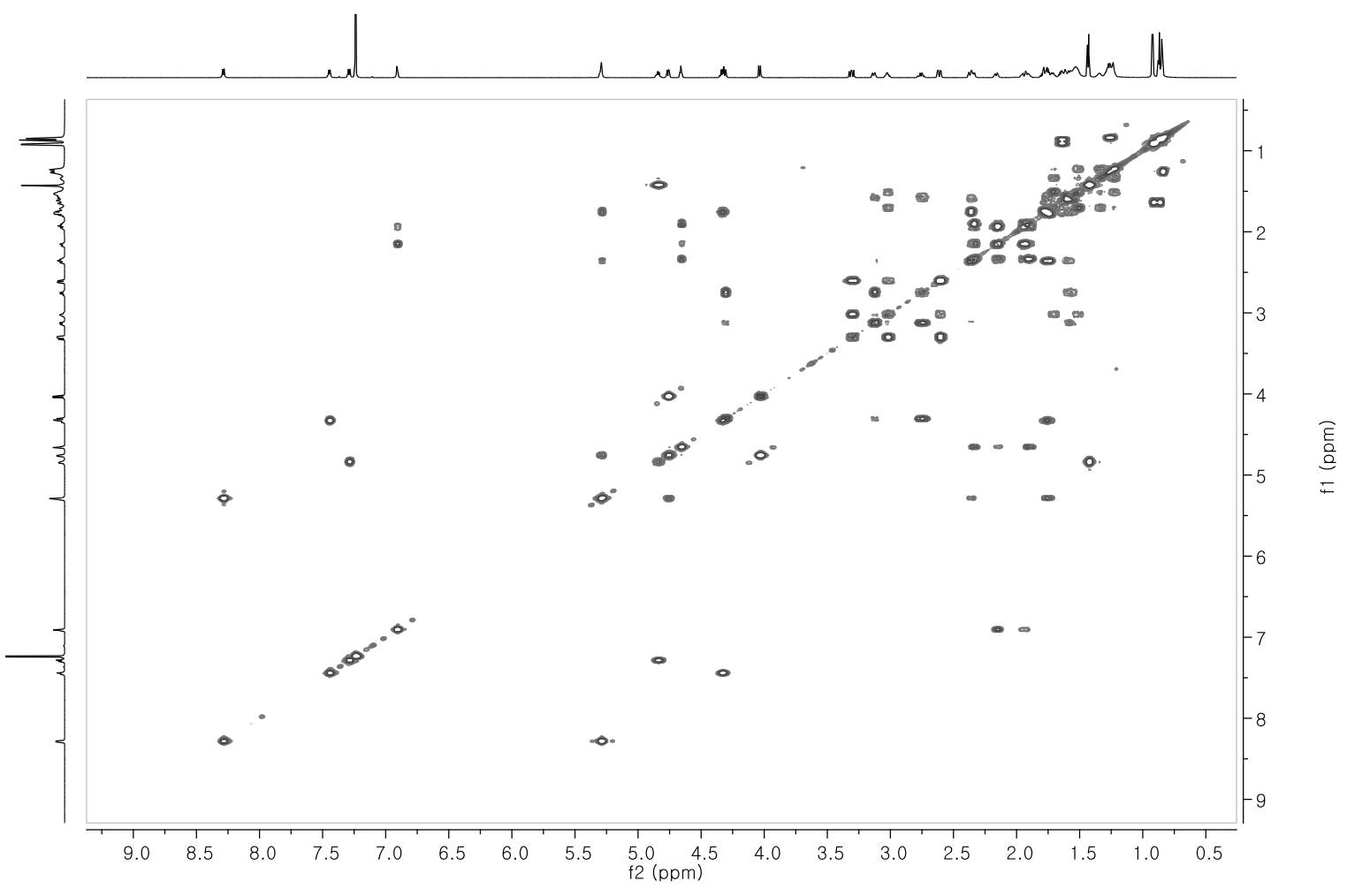

Figure S11. HSQC spectrum of lydiamycin A (1) at $800 \mathrm{MHz}$ in $\mathrm{CDCl}_{3}$.

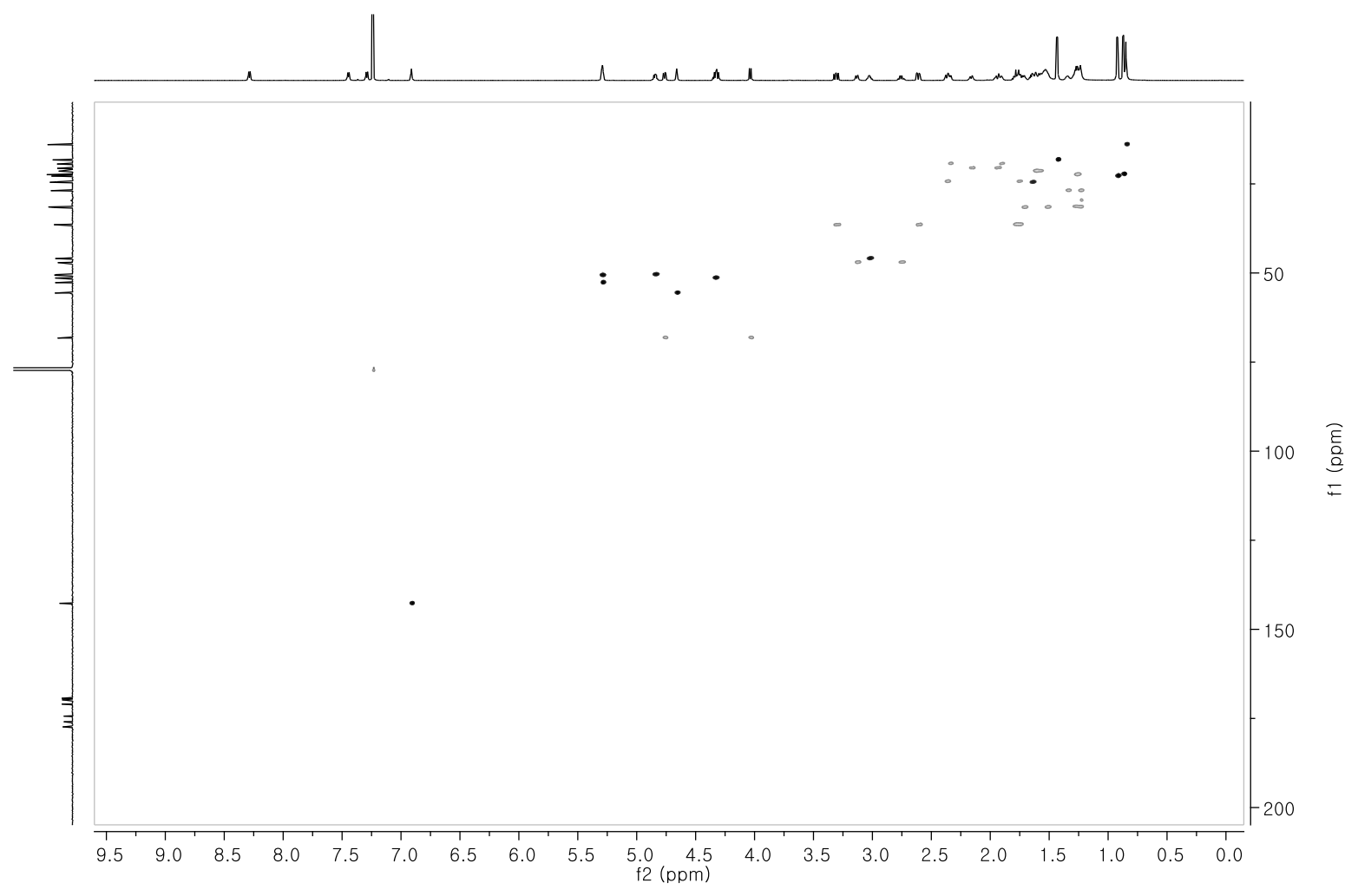


Figure S12. HMBC spectrum of lydiamycin A (1) at $800 \mathrm{MHz}$ in $\mathrm{CDCl}_{3}$.

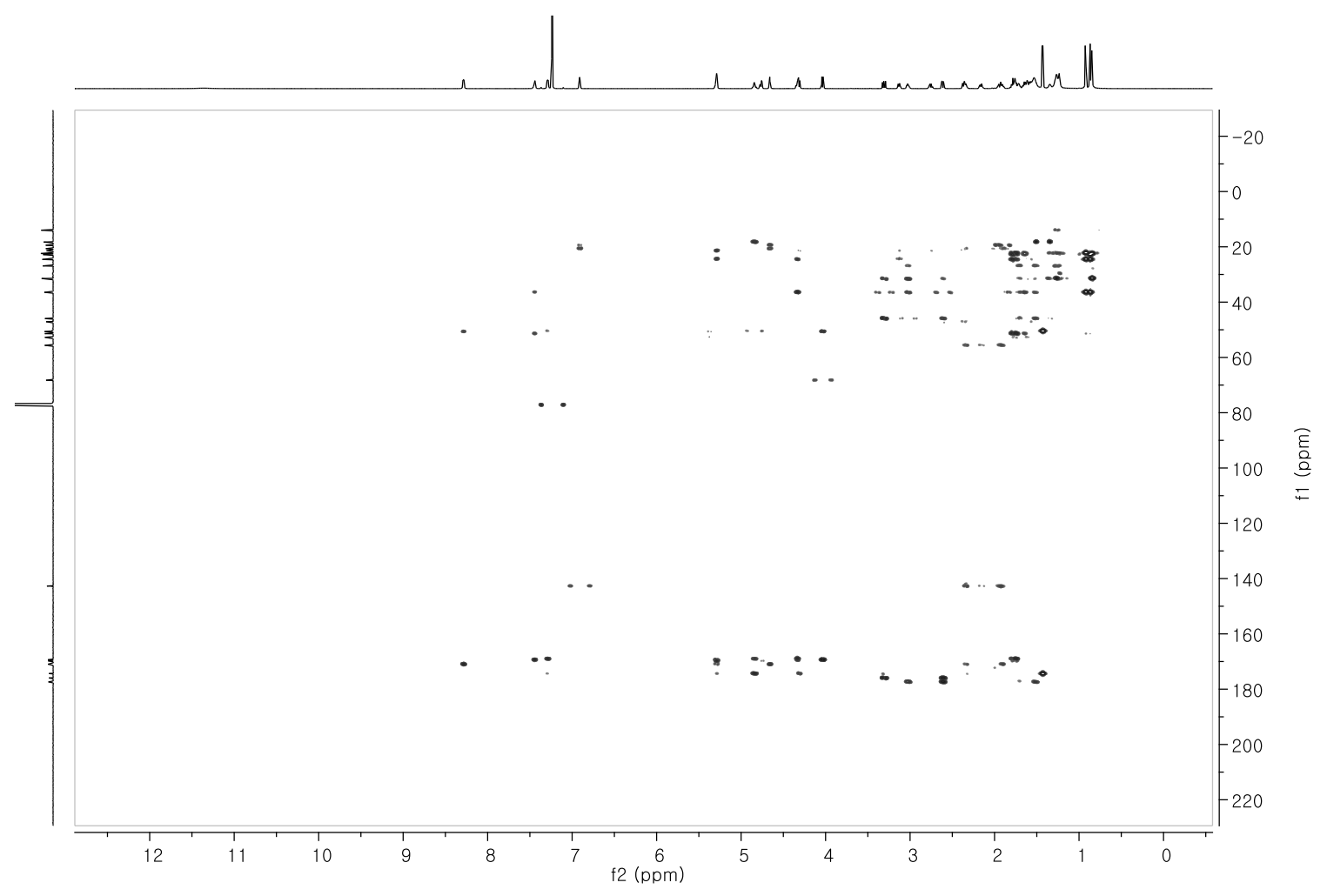

Figure S13. NOESY spectrum of lydiamycin A (1) at $800 \mathrm{MHz}$ in $\mathrm{CDCl}_{3}$.

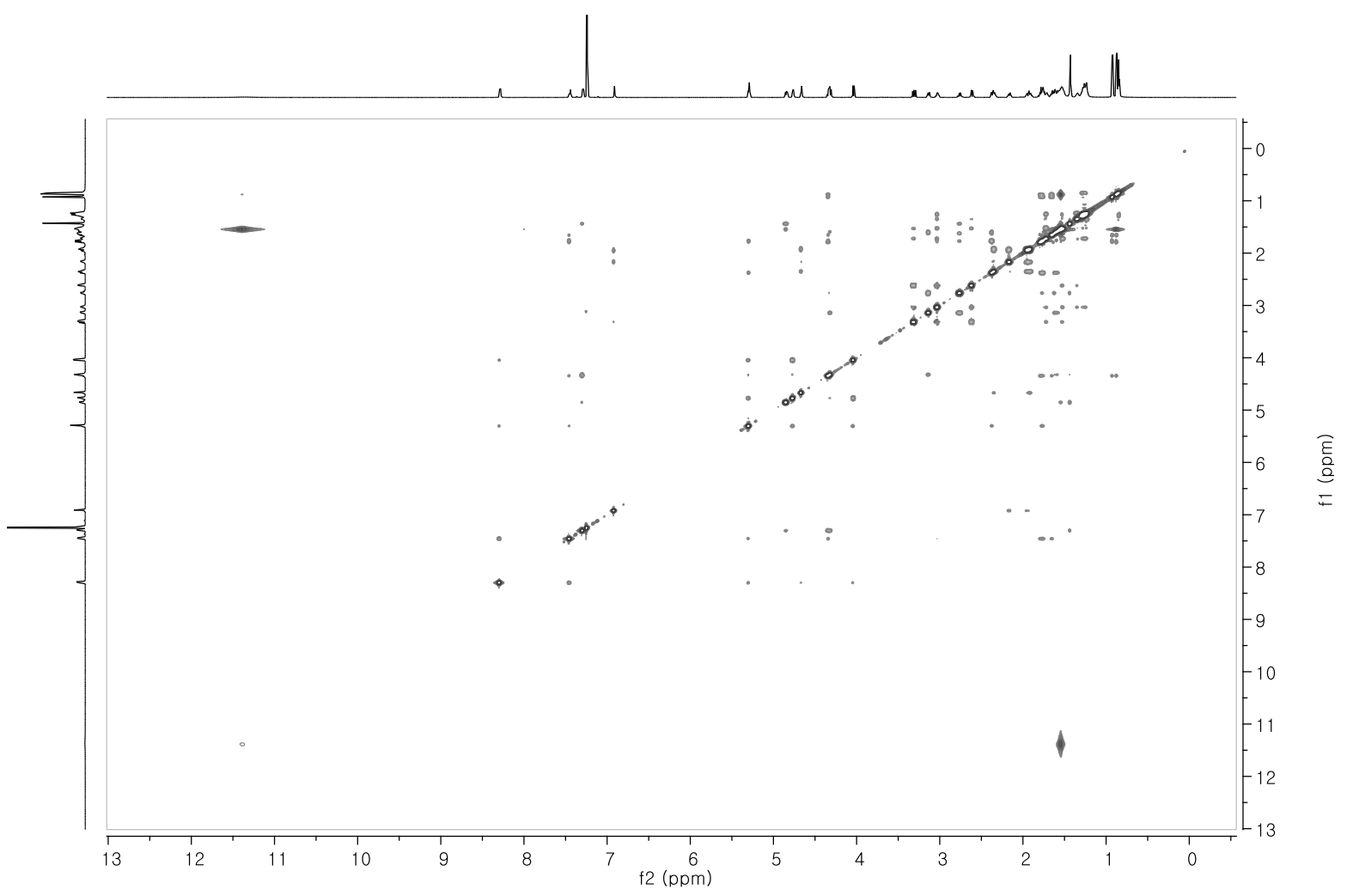




\section{Determination of the absolute configurations of the amino acid units}

Lydiamycin A (1) $(1.5 \mathrm{mg})$ was hydrolyzed in $6 \mathrm{~N} \mathrm{HCl}$ at $115^{\circ} \mathrm{C}$ for $2 \mathrm{~h}$. After removing the $\mathrm{HCl}$ in vacuo, the hydrolysate was divided into two vials. The hydrolysate was dissolved in $200 \mu \mathrm{L}$ of $1 \mathrm{~N}$ $\mathrm{NaHCO}_{3}$, and L- and D-FDAA ( $100 \mu \mathrm{L}$ of $10 \mathrm{mg} / \mathrm{mL}$ in acetone) were each added to one of the reaction vials. The reactions were maintained at $80^{\circ} \mathrm{C}$ for $3 \mathrm{~min}$. The reaction mixtures were then neutralized with $100 \mu \mathrm{L}$ of $2 \mathrm{~N} \mathrm{HCl}$ and dried in vacuo. The reaction products were dissolved in $300 \mu \mathrm{L}$ of $\mathrm{MeOH}$, and $20 \mu \mathrm{L}$ of each reaction mixture was analyzed by LC/MS using a Phenomenex $\mathrm{C}_{18}$ (2) column (Luna, $100 \times 4.6 \mathrm{~mm}, 5 \mu \mathrm{m}$ ) under gradient solvent conditions (flow rate $0.7 \mathrm{~mL} / \mathrm{min}$; UV $340 \mathrm{~nm}$ detection; $10 \%$ to $60 \% \mathrm{CH}_{3} \mathrm{CN} / \mathrm{H}_{2} \mathrm{O}$ with $0.1 \%$ formic acid over $50 \mathrm{~min}$ ).

Table S2. LC/MS analysis of L- and D-FDAA derivatives of lydiamycin A (1)

\begin{tabular}{|c|c|c|c|c|c|}
\hline \multicolumn{7}{|c|}{ Lydiamycin A (1) } \\
\hline & Ala & Ser & Leu & Pip & $\Delta$ Pip \\
\hline$[\mathrm{M}+\mathrm{H}]^{+}(m / z)$ & 342 & 358 & 384 & 383 & 381 \\
\hline Retention time (min) & \multicolumn{7}{|l|}{} \\
\hline L-FDAA & 23.4 & 18.3 & 38.2 & 24.3 & 23.3 \\
\hline D-FDAA & 26.1 & 18.5 & 33.9 & 21.5 & 23.0 \\
\hline Elution order & $\mathrm{L} \rightarrow \mathrm{D}$ & $\mathrm{L} \rightarrow \mathrm{D}$ & $\mathrm{D} \rightarrow \mathrm{L}$ & $\mathrm{D} \rightarrow \mathrm{L}$ & $\mathrm{D} \rightarrow \mathrm{L}$ \\
\hline Supposed configuration & $\mathrm{L}$ & $\mathrm{L}$ & $\mathrm{D}$ & $\mathrm{S}$ & $\mathrm{S}$ \\
\hline
\end{tabular}

Figure S14. Computational 3D models of $2 S$ (left) and $2 R$ (right) of lydiamycin A (1).

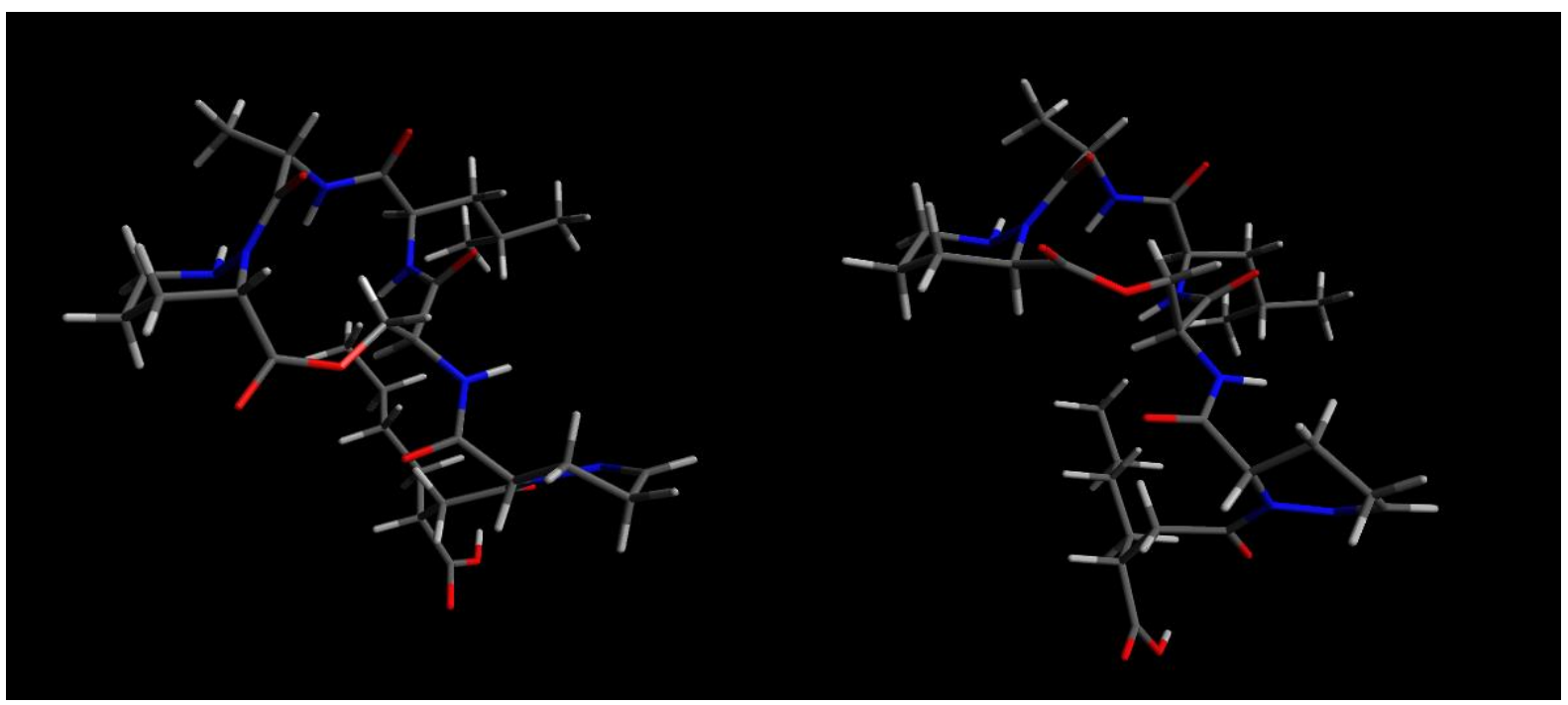




\section{Analysis of the structure of the FDAA adducts of piperazic acid}

Depsidomycin B $(10 \mathrm{mg})$, a previously reported $S$-piperazic acid-bearing depsipeptide, ${ }^{1}$ was hydrolyzed in $6 \mathrm{~N} \mathrm{HCl}$ at $115^{\circ} \mathrm{C}$ for $2 \mathrm{~h}$. After removing the $\mathrm{HCl}$ in vacuo, the hydrolysate was divided into two vials. The hydrolysate in the reaction vials was dissolved in $200 \mu \mathrm{L}$ of $1 \mathrm{~N} \mathrm{NaHCO}_{3}$, and L- and DFDAA $(100 \mu \mathrm{L}$ of $10 \mathrm{mg} / \mathrm{mL}$ in acetone) were each added to one reaction vial. The reaction was maintained at $80{ }^{\circ} \mathrm{C}$ for $3 \mathrm{~min}$. The reaction mixtures were neutralized with $100 \mu \mathrm{L}$ of $2 \mathrm{~N} \mathrm{HCl}$ and dried in vacuo. The reaction products were dissolved in $500 \mu \mathrm{L}$ of MeOH. L-FDAA-S-piperazic acid and D-FDAA-S-piperazic acid were purified by HPLC on a YMC-Triart $\mathrm{C}_{18}$ column $(250 \times 10 \mathrm{~mm})$ with gradient solvent conditions (flow rate $2 \mathrm{~mL} / \mathrm{min}$; UV $360 \mathrm{~nm}$ detection; $30 \%$ to $50 \% \mathrm{CH}_{3} \mathrm{CN} / \mathrm{H}_{2} \mathrm{O}$ with $0.1 \%$ formic acid over $40 \mathrm{~min})$. Both L-FDAA- $S$-piperazic acid $(1.0 \mathrm{mg}, 20 \%$ yield) and D-FDAA$S$-piperazic acid $(1.0 \mathrm{mg}, 20 \%$ yield) eluted at $24 \mathrm{~min}$ under the purification conditions as yellowish amorphous solid.

Figure S15. ${ }^{1} \mathrm{H}$ NMR spectrum of reaction product of $S$-piperazic acid with L-FDAA at $800 \mathrm{MHz}$ in DMSO- $d_{6}$.

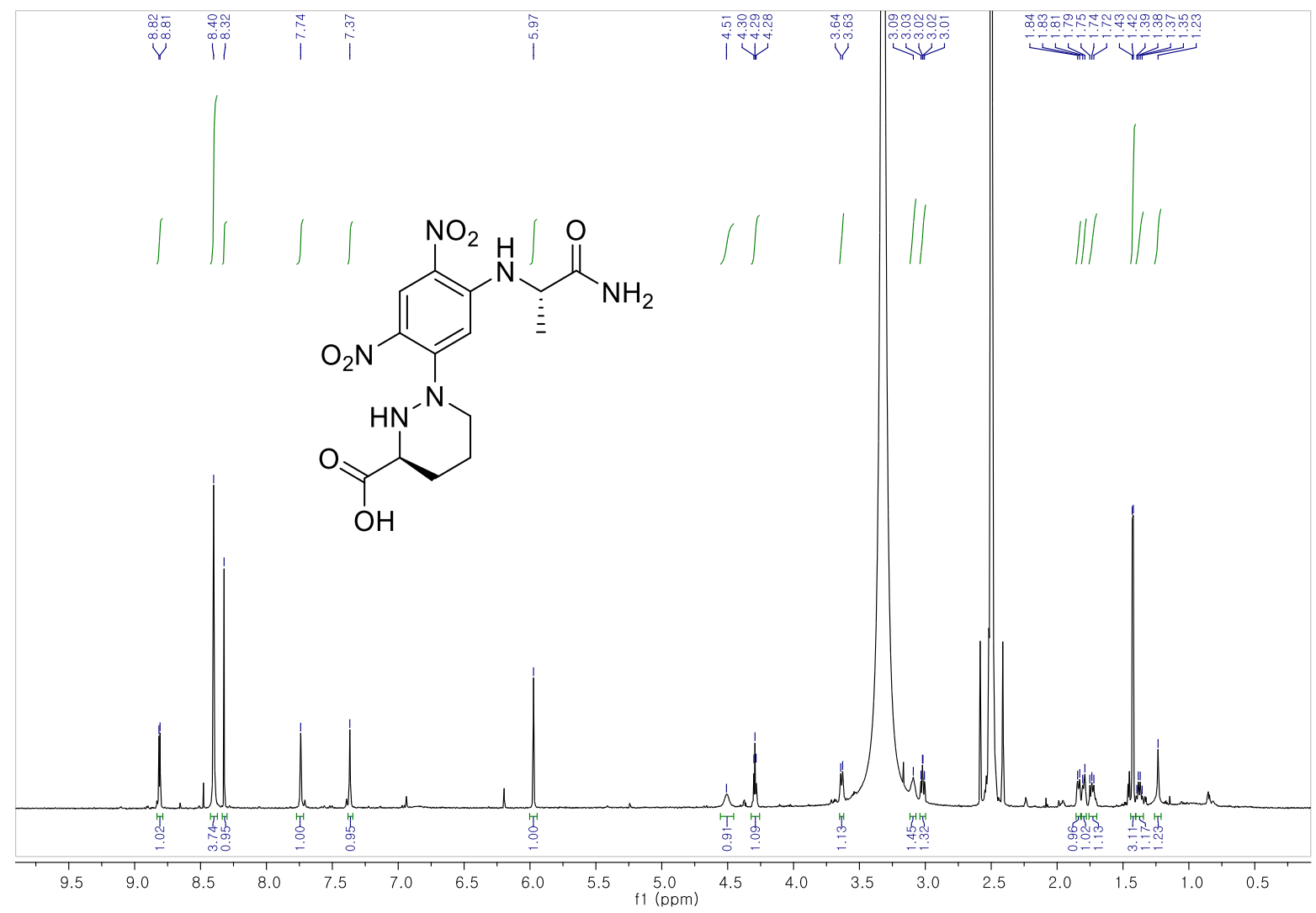


Figure S16. HSQC spectrum of reaction product of $S$-piperazic acid with L-FDAA at $800 \mathrm{MHz}$ in DMSO- $d_{6}$.

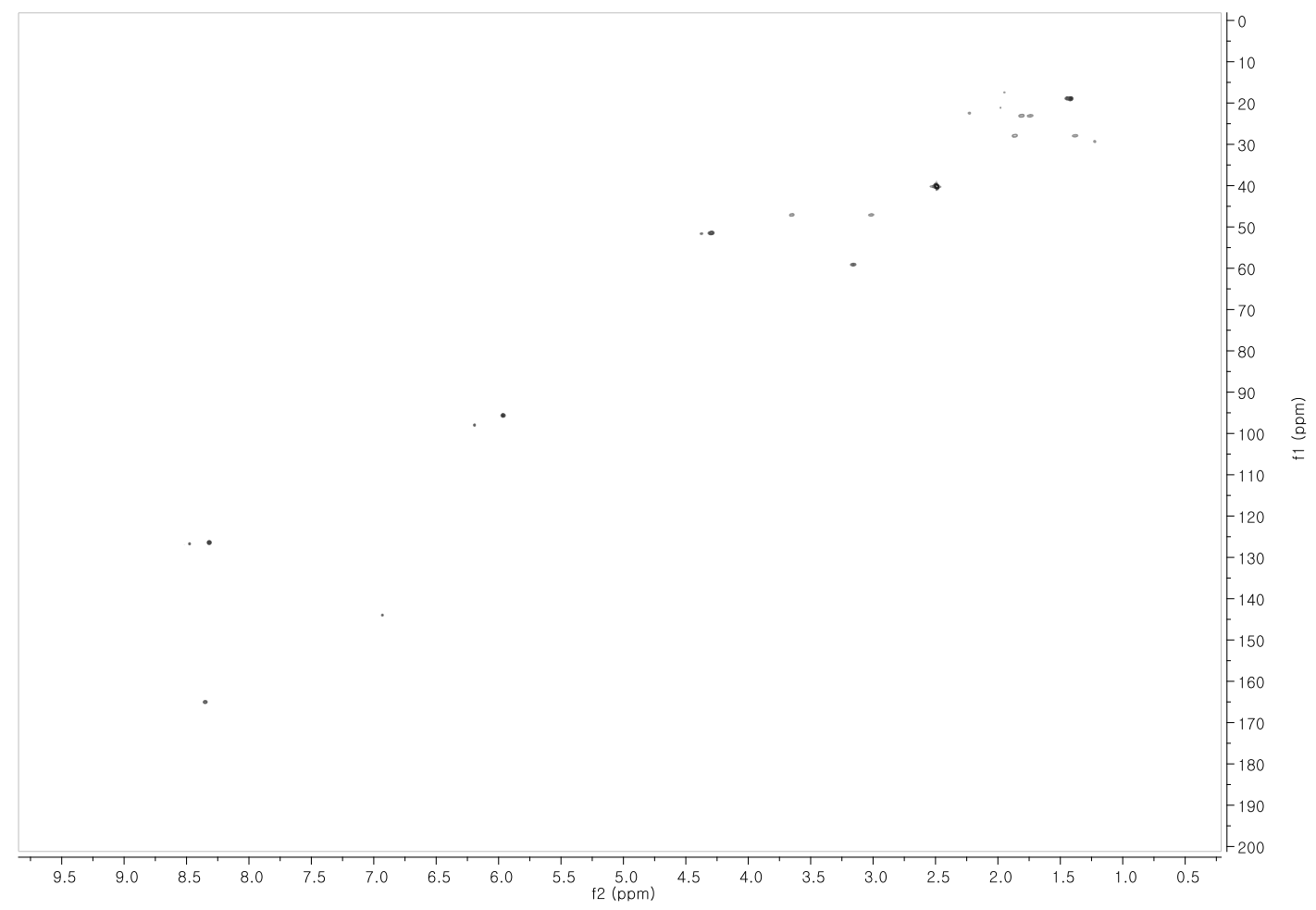

Figure S17. COSY spectrum of reaction product of $S$-piperazic acid with L-FDAA at $800 \mathrm{MHz}$ in DMSO- $d_{6}$.

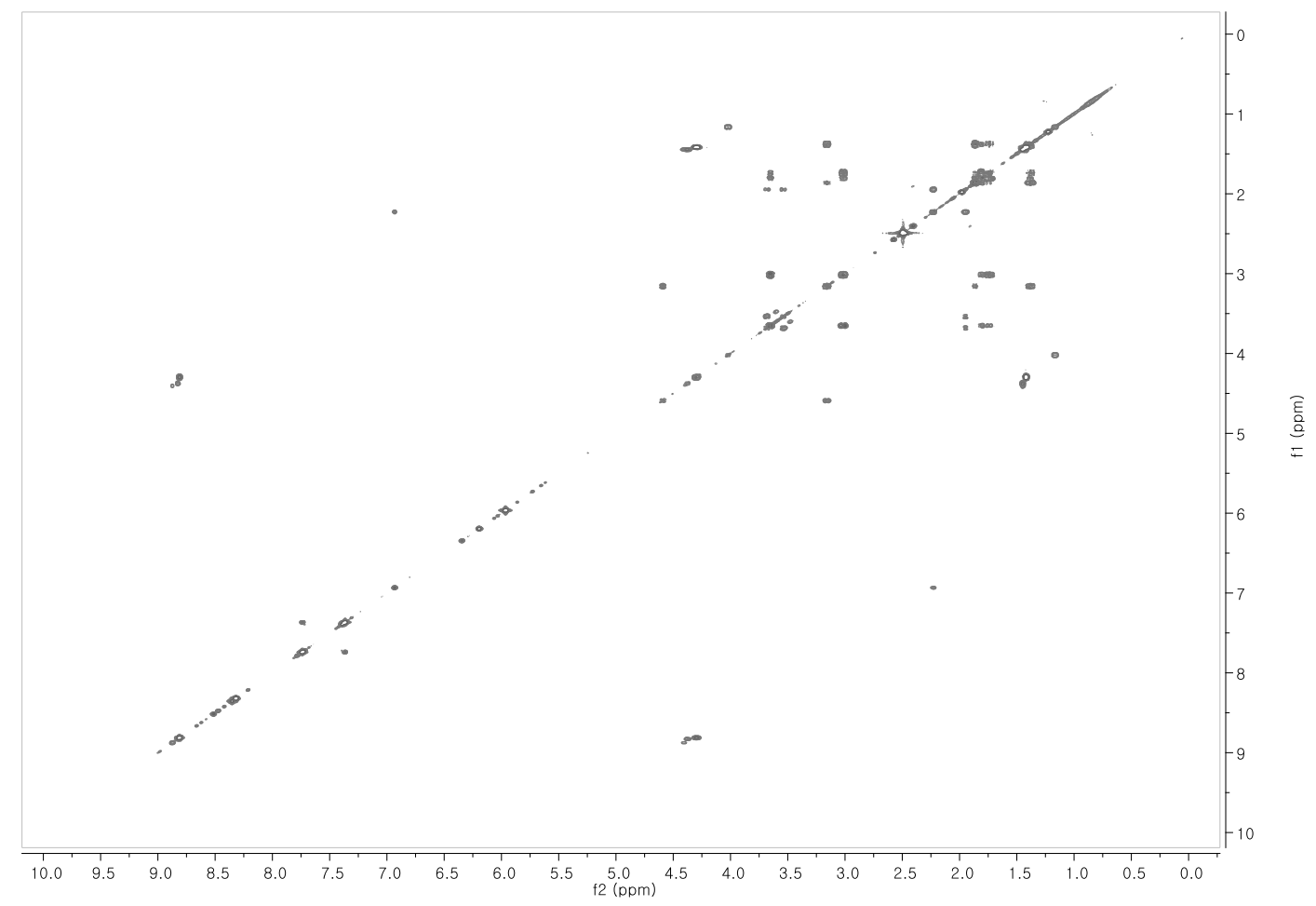


Figure S18. ROESY spectrum of reaction product of $S$-piperazic acid with L-FDAA at $800 \mathrm{MHz}$ in DMSO- $d_{6}$.

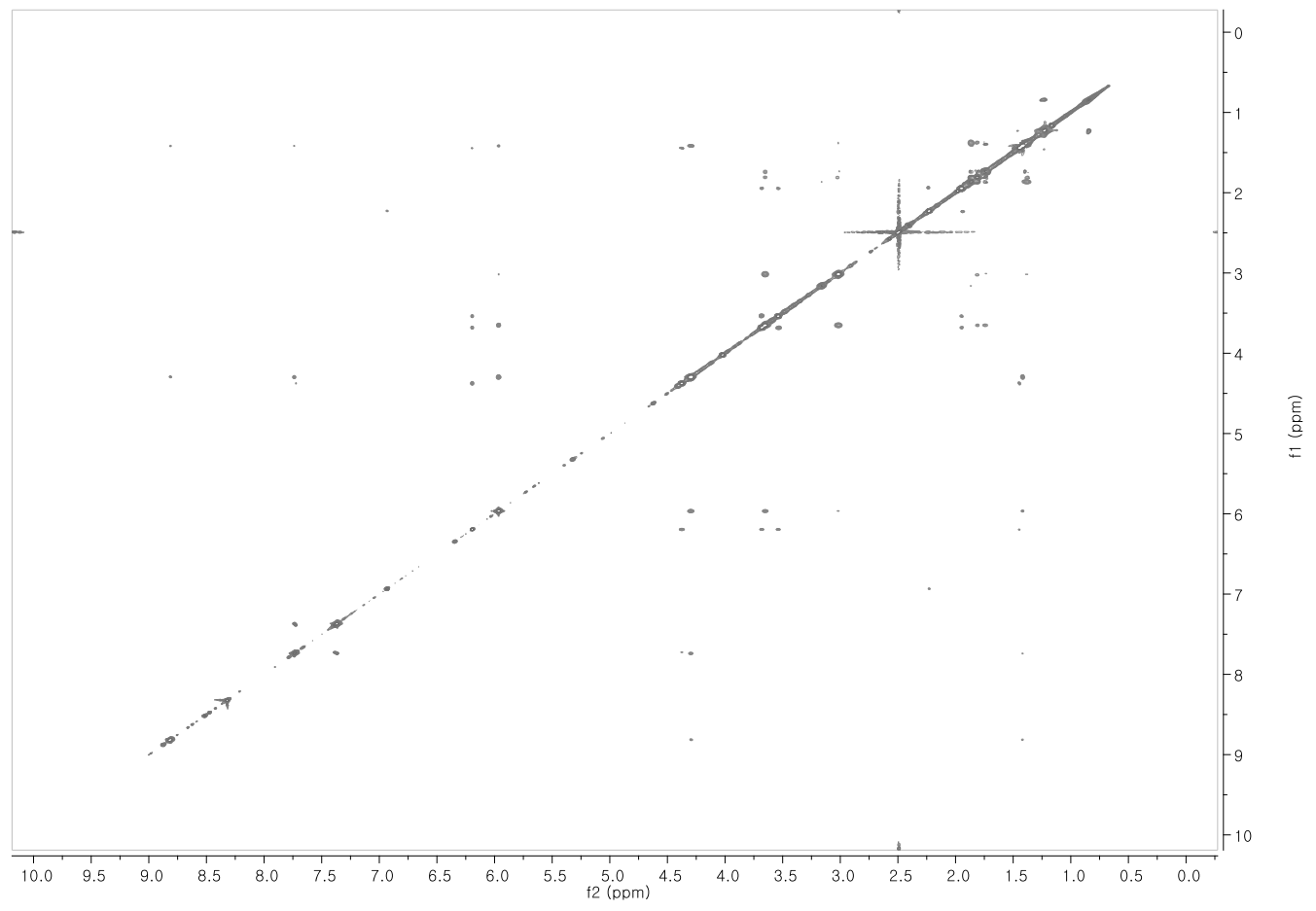

Figure S19. ${ }^{1} \mathrm{H}$ NMR spectrum of reaction product of $S$-piperazic acid with D-FDAA at $800 \mathrm{MHz}$ in DMSO- $d_{6}$.

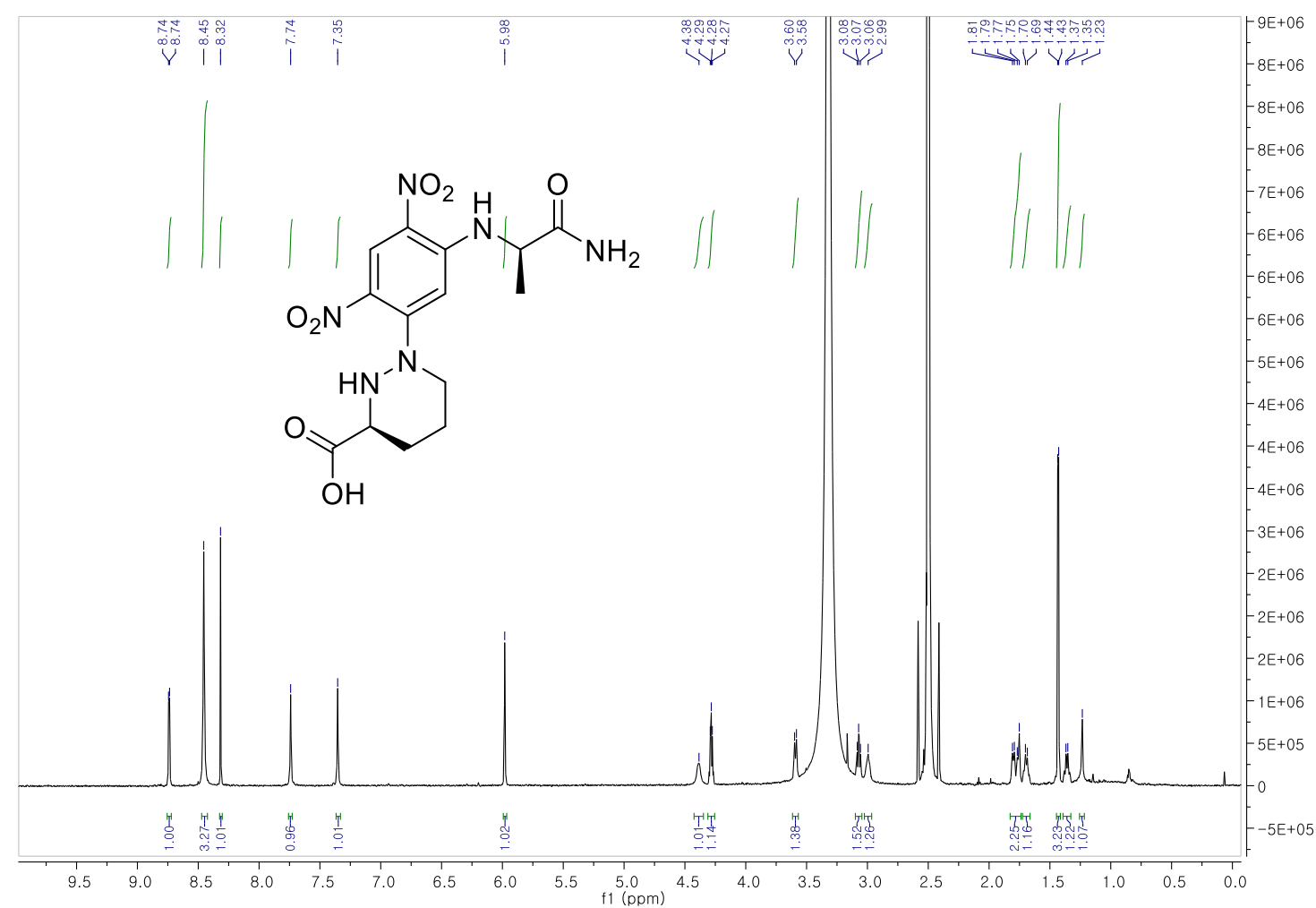


Figure S20. HSQC spectrum of reaction product of $S$-piperazic acid with D-FDAA at $800 \mathrm{MHz}$ in DMSO- $d_{6}$.

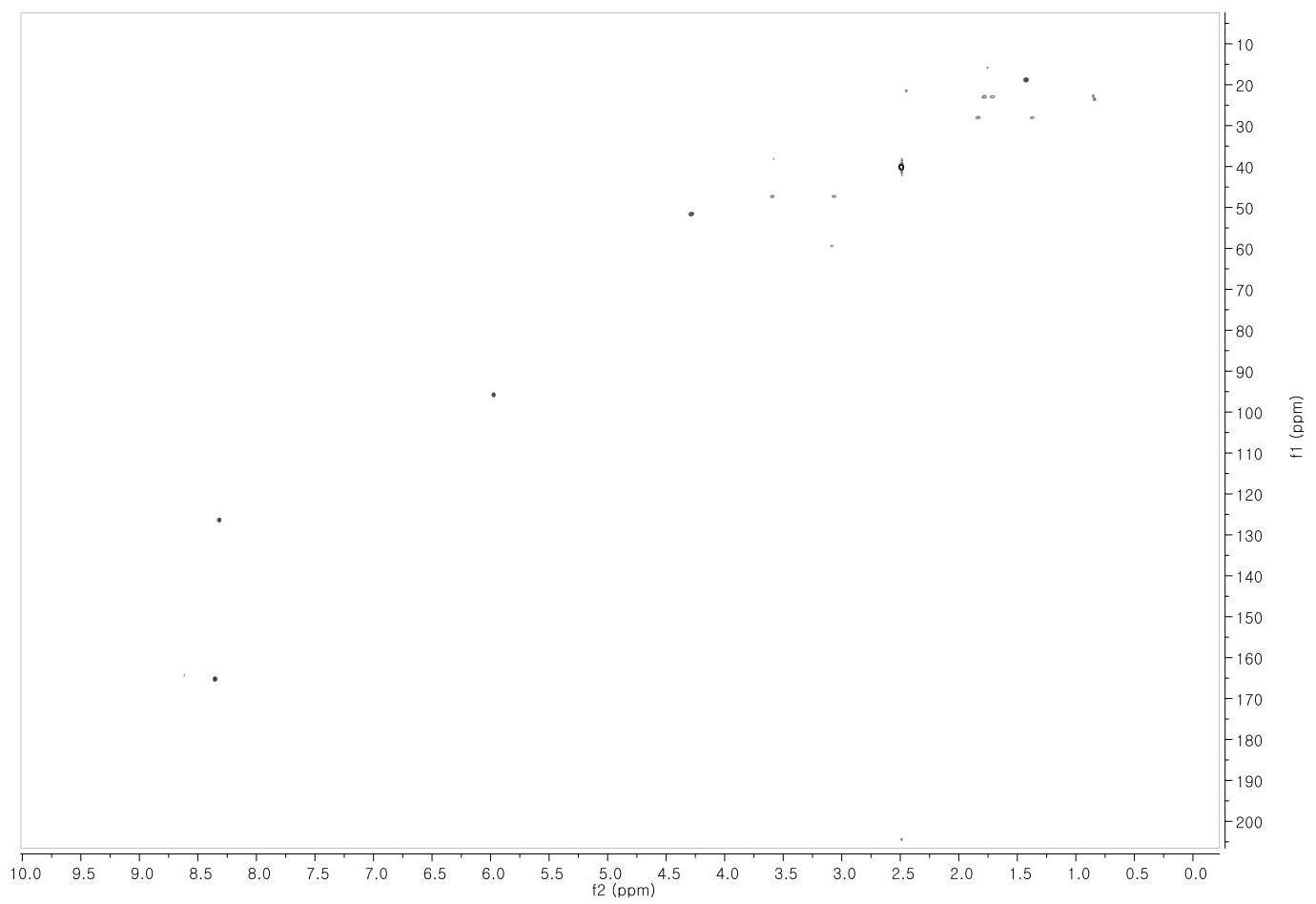

Figure S21. COSY spectrum of reaction product of $S$-piperazic acid with D-FDAA at $800 \mathrm{MHz}$ in DMSO- $d_{6}$.

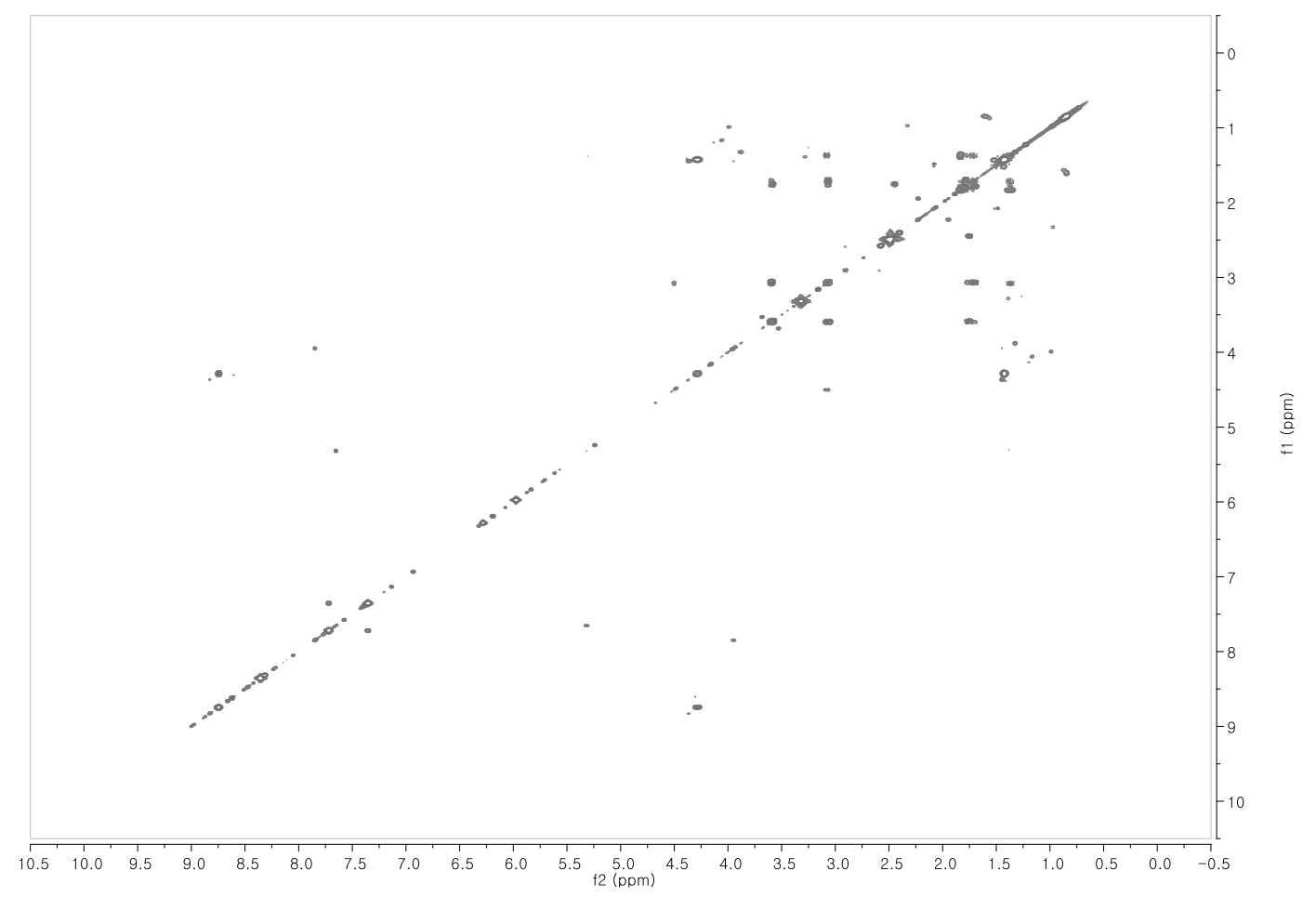


Figure S22. ROESY spectrum of reaction product of $S$-piperazic acid with D-FDAA at $800 \mathrm{MHz}$ in DMSO- $d_{6}$.

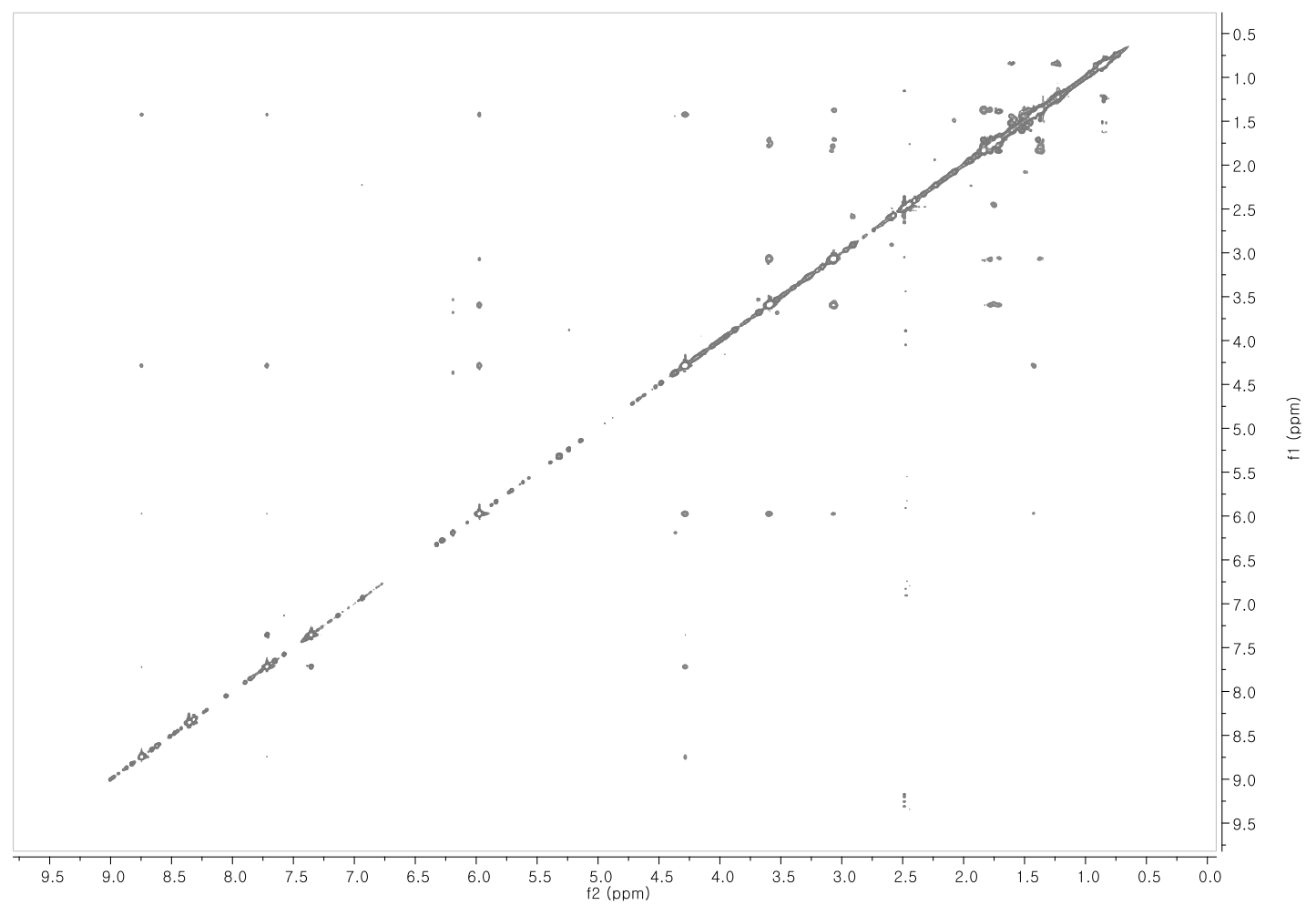


Figure S23. Computational 3D models of reaction product of $S$-piperazic acid with (a) L- and (b) D-FDAA reagents.

(a)

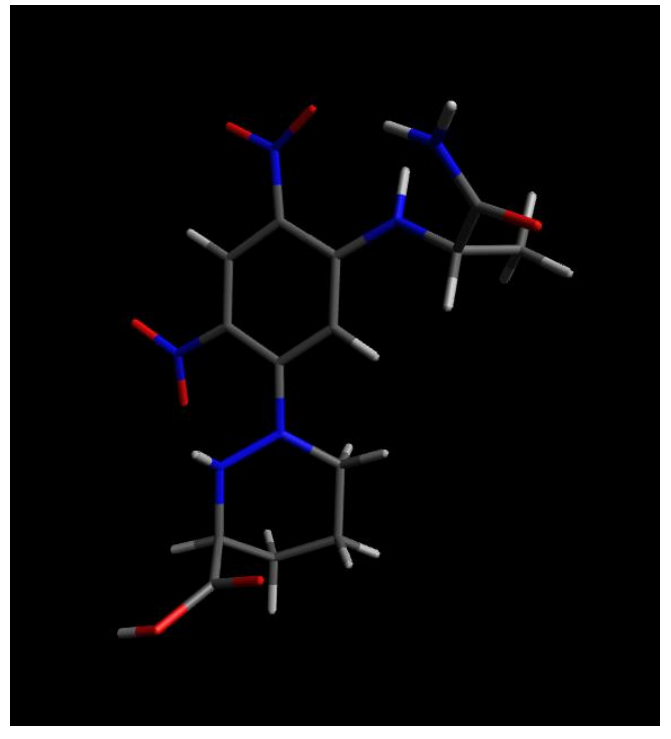

(b)

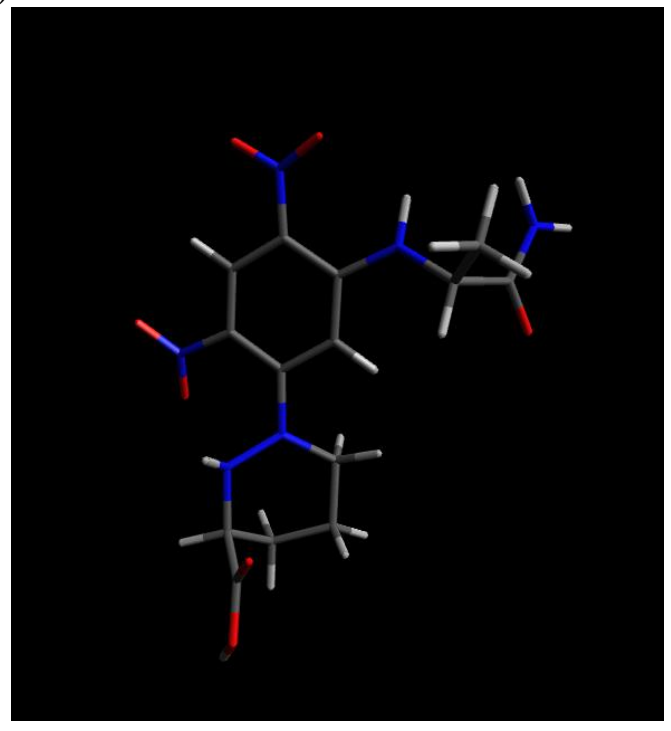




\section{Reduction of lydiamycin A and analysis of the FDAA adducts of piperazic acid}

Lydiamycin A (1) (1 mg) was dried in a 40-mL vial under high vacuum. The dried compound was dissolved in $1 \mathrm{~mL}$ of a 2:1 mixture of acetic acid and $\mathrm{MeOH}$. $\mathrm{NaBH}_{3} \mathrm{CN}(2 \mathrm{mg})$ was added to the solution, and the reaction mixture was stirred at room temperature under argon for $1 \mathrm{~h}$. The reaction was quenched by adding $200 \mu \mathrm{L}$ of $10 \%$ aqueous $\mathrm{HCl}$ solution. The reaction product was confirmed by the expected molecular ion by LC/MS analysis (ESI-LRMS $m / z$ : $[\mathrm{M}+\mathrm{H}]^{+}$Calcd for $\mathrm{C}_{31} \mathrm{H}_{52} \mathrm{~N}_{7} \mathrm{O}_{9}, 666$; Found 666). The fraction of residue was subjected to the advanced Marfey's analysis following the same procedure mentioned above.

Figure S24. LC/MS analysis of the FDAA adducts of the reduction product of 1 .

(a) Extract negative ion of piperazic acid reacted with L-FDAA product $(\mathrm{m} / \mathrm{z}=381)$

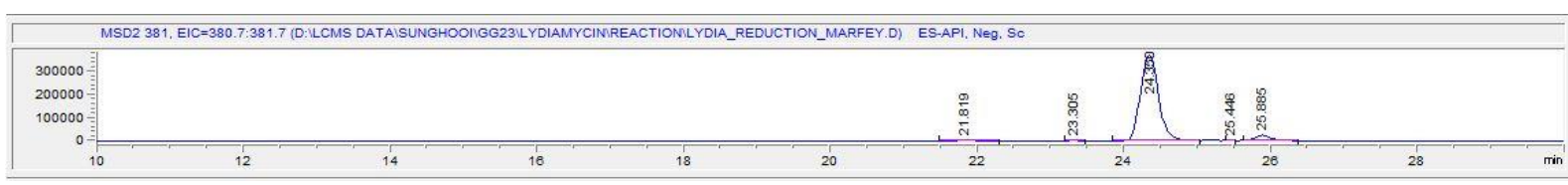

(b) Extract negative ion of piperazic acid reacted with D-FDAA product $(\mathrm{m} / \mathrm{z}=381)$

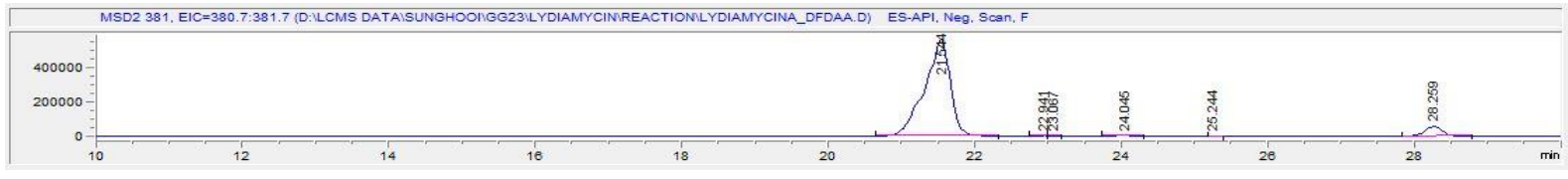

(c) Extract negative ion of dehydropiperazic acid reacted with L-FDAA product $(\mathrm{m} / \mathrm{z}=379)$

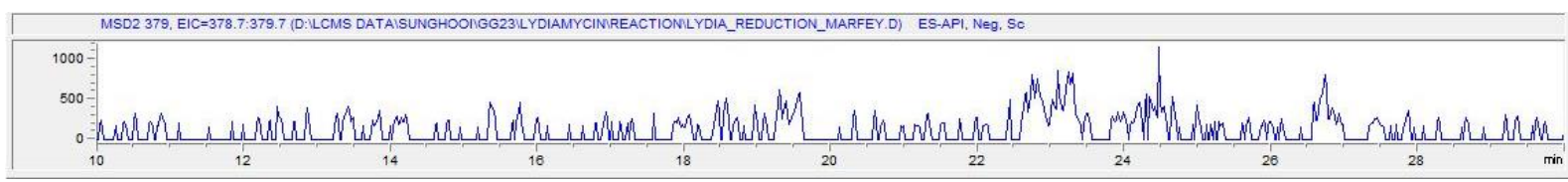

(d) Extract negative ion of dehydropiperazic acid reacted with D-FDAA product $(\mathrm{m} / \mathrm{z}=379)$

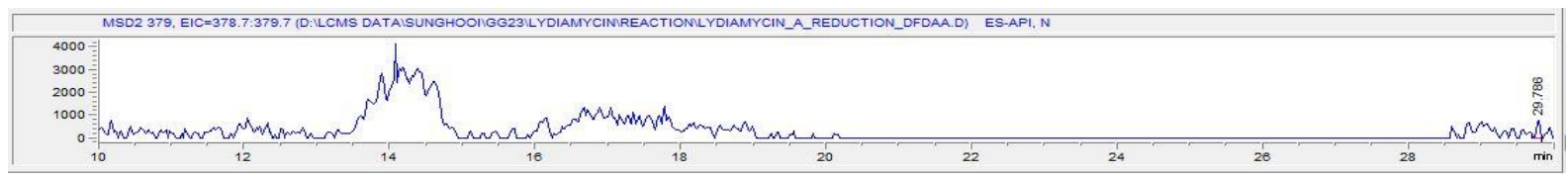

Table S3. LC/MS analysis of L- and D-FDAA derivatives of the reduction product of 1

\begin{tabular}{|c|c|c|c|c|c|}
\hline \multicolumn{7}{|c|}{ Reduction product of lydiamycin A } \\
\hline & Ala & Ser & Leu & Pip & $\Delta$ Pip \\
\hline$[\mathrm{M}-\mathrm{H}]^{-}(\mathrm{m} / \mathrm{z})$ & 340 & 356 & 382 & 381 & 379 \\
\hline Retention time (min) & \multicolumn{7}{|c|}{} & \\
\hline L-FDAA & 23.4 & 18.3 & 38.2 & 24.3 & not detected \\
\hline D-FDAA & 26.0 & 18.5 & 33.9 & 21.5 & not detected \\
\hline Elution order & L $\rightarrow \mathrm{D}$ & $\mathrm{L} \rightarrow \mathrm{D}$ & $\mathrm{D} \rightarrow \mathrm{L}$ & $\mathrm{D} \rightarrow \mathrm{L}$ & \\
\hline Supposed configuration & $\mathrm{L}$ & $\mathrm{L}$ & $\mathrm{D}$ & $\mathrm{S}$ & \\
\hline
\end{tabular}




\section{Conformational search and DP4 analysis of lydiamycin A (1)}

A conformational search of lydiamycin A (1) was performed using MacroModel with the Merck molecular force field (gas phase), a $10 \mathrm{~kJ} / \mathrm{mol}$ upper energy limit, and a $0.001 \mathrm{~kJ}(\mathrm{~mol} \AA)^{-1}$ convergence threshold on the rms gradient to minimize computational complexity and expense. Twenty-three conformers were obtained for the $19 S$ diastereomer, and 81 conformers were obtained for the $19 R$ model under the $10 \mathrm{~kJ} / \mathrm{mol}$ limit. The Boltzmann population of each conformer was calculated. Ground state geometry optimization of each conformer was carried out by density functional theory (DFT) modeling and TurbomoleX 4.3.2. The basis set for the calculation was def-SV(P) for all atoms, and the level of theory was B3-LYP at the functional level in the gas phase. The calculated ${ }^{1} \mathrm{H}$ and ${ }^{13} \mathrm{C}$ chemical shift values were averaged by the Boltzmann populations. By comparing these Boltzmann averaged chemical shifts and the experimental chemical shifts, the DP4 analyses indicated the $14 S$ configuration of 1 with $100.0 \%$ probability.

Figure S25. Result of DP4 calculation from the simulated models of two possible diastereomers $(19 S, 19 R)$.<smiles>CCCCC[C@H](C)CC(=O)N1N=CCC[C@H]1C(=O)N[C@@H](COC(=O)[C@@H]1CCCNN1C(=O)[C@@H](C)NC(=O)[C@H](C)NC(=O)[C@H]1CCCNN1C(=O)O)CC(C)C</smiles>

Diastereomer 1 (19S)<smiles>CCCCC[C@H](C)CC(=O)N1N=CCC[C@H]1C(=O)N[C@@H](COC(=O)[C@@H]1CCCNN1C(=O)[C@@H](C)NC(=O)[C@H](C)NC(=O)[C@H]1CCCNN1C(=O)O)CC(C)C</smiles>

Diastereomer $2(19 R)$

\section{DP4 Calculation result}

\section{Both carbon and proton data:}

Diastereomer $1(19 S)-100.0 \%$

Diastereomer $2(19 R)-0.0 \%$

\section{Carbon data only:}

Diastereomer $1(19 S)-100.0 \%$

Diastereomer $2(19 R)-0.0 \%$

\section{Proton data only:}

Diastereomer $1(19 S)-100.0 \%$

Diastereomer $2(19 R)-0.0 \%$ 
Table S4. The major conformers of lydiamycin A (1) identified by conformational searches in MMFF94 force field using the macromodel

\begin{tabular}{|c|c|c|}
\hline Conformers & Relative energy (kJ/mol) & Boltzmann population (\%) \\
\hline $19 S \_1$ & 0.000 & 20.291 \\
\hline $19 S \_2$ & 0.617 & 15.823 \\
\hline 19S_3 & 1.771 & 9.931 \\
\hline 19S_4 & 1.935 & 9.296 \\
\hline $19 S \_5$ & 2.448 & 7.558 \\
\hline $19 S \_6$ & 3.039 & 5.954 \\
\hline $19 S \_7$ & 3.167 & 5.655 \\
\hline 19S_8 & 3.536 & 4.873 \\
\hline $19 S \_9$ & 3.988 & 4.061 \\
\hline $19 S \_10$ & 4.739 & 2.999 \\
\hline $19 S \_11$ & 5.027 & 2.67 \\
\hline $19 S \_12$ & 5.914 & 1.867 \\
\hline 19S_13 & 6.305 & 1.595 \\
\hline $19 S_{-} 14$ & 6.420 & 1.522 \\
\hline $19 S \_15$ & 7.099 & 1.157 \\
\hline $19 S \_16$ & 7.398 & 1.026 \\
\hline 19S_17 & 8.329 & 0.705 \\
\hline 19S_18 & 8.498 & 0.658 \\
\hline 19S_19 & 8.693 & 0.608 \\
\hline $19 S \_20$ & 9.066 & 0.524 \\
\hline $19 S \_21$ & 9.444 & 0.449 \\
\hline $19 S \_22$ & 9.650 & 0.414 \\
\hline 19S_23 & 9.984 & 0.361 \\
\hline $\begin{array}{ll}19 R \_1 \\
\end{array}$ & $\overline{c 0.000}$ & $\begin{array}{l}10.27 \\
\end{array}$ \\
\hline $19 R_{-} 2$ & 0.648 & 7.907 \\
\hline $19 R \_3$ & 0.828 & 7.354 \\
\hline $19 R \_4$ & 1.003 & 6.852 \\
\hline $19 R \_5$ & 1.399 & 5.84 \\
\hline $19 R \_6$ & 1.624 & 5.335 \\
\hline $19 R \_7$ & 2.470 & 3.792 \\
\hline $19 R \_8$ & 3.258 & 2.759 \\
\hline $19 R_{-} 9$ & 3.455 & 2.549 \\
\hline $19 R \_10$ & 3.763 & 2.25 \\
\hline $19 R \_11$ & 3.890 & 2.138 \\
\hline $19 R \_12$ & 4.086 & 1.976 \\
\hline $19 R \_13$ & 4.096 & 1.968 \\
\hline 19R_14 & 4.425 & 1.723 \\
\hline $19 R \_15$ & 4.459 & 1.7 \\
\hline $19 R \_16$ & 4.506 & 1.668 \\
\hline $19 R \_17$ & 4.596 & 1.608 \\
\hline 19R_18 & 4.843 & 1.456 \\
\hline 19R_19 & 5.029 & 1.35 \\
\hline $19 R \_20$ & 5.347 & 1.188 \\
\hline $19 R \_21$ & 5.404 & 1.161 \\
\hline 19R_22 & 5.445 & 1.142 \\
\hline 19R_23 & 5.479 & 1.126 \\
\hline $19 R \_24$ & 5.521 & 1.107 \\
\hline $19 R \_25$ & 5.535 & 1.101 \\
\hline 19R_26 & $\begin{array}{l}5.768 \\
\end{array}$ & 1.002 \\
\hline $19 R \_27$ & 5.954 & 0.93 \\
\hline $19 R \_28$ & 6.036 & 0.9 \\
\hline 19R_29 & 6.190 & 0.845 \\
\hline $19 R \_30$ & 6.199 & 0.842 \\
\hline $19 R \_31$ & 6.242 & 0.828 \\
\hline 19R_32 & 6.261 & 0.822 \\
\hline $19 R \_33$ & 6.444 & 0.763 \\
\hline $19 R \_34$ & 7.040 & 0.6 \\
\hline $19 R \_35$ & 7.070 & 0.593 \\
\hline $19 R \_36$ & 7.237 & 0.554 \\
\hline $19 R \_37$ & 7.257 & 0.55 \\
\hline $19 R \_38$ & 7.305 & 0.539 \\
\hline $19 R \_39$ & 7.544 & 0.49 \\
\hline $19 R \_40$ & 7.760 & 0.45 \\
\hline 19R_41 & 7.782 & 0.445 \\
\hline
\end{tabular}




\begin{tabular}{|c|c|c|}
\hline $19 R \_42$ & 7.806 & 0.441 \\
\hline 19R_43 & 7.808 & 0.44 \\
\hline 19R_44 & 7.812 & 0.439 \\
\hline $19 R \_45$ & 7.833 & 0.436 \\
\hline 19R_46 & 7.870 & 0.429 \\
\hline 19R_47 & 7.994 & 0.408 \\
\hline $19 R \_48$ & 8.003 & 0.407 \\
\hline 19R_49 & 8.115 & 0.389 \\
\hline 19R_50 & 8.374 & 0.35 \\
\hline $19 R \_51$ & 8.407 & 0.346 \\
\hline 19R_52 & 8.420 & 0.344 \\
\hline 19R_53 & 8.448 & 0.34 \\
\hline 19R_54 & 8.464 & 0.338 \\
\hline $19 R \_55$ & 8.515 & 0.331 \\
\hline 19R_56 & 8.694 & 0.308 \\
\hline 19R_57 & 8.882 & 0.285 \\
\hline 19R_58 & 8.905 & 0.283 \\
\hline 19R_59 & 8.919 & 0.281 \\
\hline 19R_60 & 8.943 & 0.278 \\
\hline 19R_61 & 9.125 & 0.259 \\
\hline 19R_62 & 9.167 & 0.254 \\
\hline 19R_63 & 9.188 & 0.252 \\
\hline 19R_64 & 9.189 & 0.252 \\
\hline 19R_65 & 9.327 & 0.238 \\
\hline 19R_66 & 9.379 & 0.234 \\
\hline 19R_67 & 9.388 & 0.233 \\
\hline 19R_68 & 9.400 & 0.232 \\
\hline 19R_69 & 9.455 & 0.226 \\
\hline 19R_70 & 9.469 & 0.225 \\
\hline 19R_71 & 9.523 & 0.22 \\
\hline 19R_72 & 9.556 & 0.217 \\
\hline $19 R \_73$ & 9.578 & 0.216 \\
\hline 19R_74 & 9.598 & 0.214 \\
\hline 19R_75 & 9.661 & 0.208 \\
\hline 19R_76 & 9.672 & 0.208 \\
\hline 19R_77 & 9.704 & 0.205 \\
\hline 19R_78 & 9.762 & 0.2 \\
\hline $19 R \_79$ & 9.894 & 0.19 \\
\hline $19 R \_80$ & 9.901 & 0.189 \\
\hline $19 R \_81$ & 9.977 & 0.184 \\
\hline
\end{tabular}


Table S5. Experimental (Exp.) and calculated (Cal.) chemical shift values (CS, $\delta$ ) of lydiamycin A (1)

\begin{tabular}{|c|c|c|c|}
\hline Atom & Cal. CS of $19 S$ & Cal. CS of $19 R$ & Exp. CS of 1 \\
\hline C-1 & 50.74 & 49.29 & 46.2 \\
\hline $\mathrm{C}-2$ & 30.08 & 24.82 & 21 \\
\hline $\mathrm{C}-3$ & 32.86 & 29.57 & 23.8 \\
\hline $\mathrm{C}-4$ & 63.1 & 61.04 & 50.6 \\
\hline $\mathrm{C}-7$ & 173.55 & 174.75 & 172 \\
\hline $\mathrm{C}-8$ & 167.89 & 168.02 & 169.4 \\
\hline C-9 & 57.38 & 57.44 & 51.6 \\
\hline C-11 & 67.78 & 68.35 & 62.8 \\
\hline C-12 & 61.94 & 62.78 & 52.8 \\
\hline C-13 & 163.62 & 163.5 & 170.3 \\
\hline C-15 & 53.66 & 53.58 & 50.8 \\
\hline C-16 & 173.18 & 170.47 & 170 \\
\hline C-18 & 45.68 & 47.75 & 37.5 \\
\hline C-19 & 31.13 & 31.48 & 24 \\
\hline C-20 & 30.71 & 30.3 & 22.8 \\
\hline C-21 & 28.65 & 29.37 & 22 \\
\hline C-22 & 22.2 & 21.8 & 16.1 \\
\hline C-24 & 166.46 & 173.64 & 169.6 \\
\hline $\mathrm{C}-25$ & 53.73 & 50.99 & 51.3 \\
\hline C-28 & 25.99 & 25.91 & 18.6 \\
\hline C-30 & 176.54 & 175.73 & 173.3 \\
\hline C-31 & 138.61 & 138.73 & 141.8 \\
\hline C-32 & 24.83 & 24.47 & 19.5 \\
\hline C-34 & 45.21 & 44.05 & 35.6 \\
\hline C-35 & 47.42 & 47.49 & 36.4 \\
\hline C-36 & 41.12 & 42.86 & 31 \\
\hline C-37 & 34.58 & 35.41 & 31.2 \\
\hline C-38 & 38.02 & 39.11 & 25.6 \\
\hline C39 & 30.78 & 31.3 & 21.8 \\
\hline C-44 & 23.1 & 23.05 & 13.8 \\
\hline C-45 & 170.69 & 168.88 & 175.2 \\
\hline H-48 & 2.51 & 2.52 & 2.62 \\
\hline H-49 & 2.71 & 2.85 & 3.02 \\
\hline $\mathrm{H}-50$ & 1.4 & 1.27 & 1.51 \\
\hline H-51 & 0.99 & 1.16 & 1.43 \\
\hline H-52 & 1.71 & 1.87 & 2.1 \\
\hline H-53 & 1.57 & 1.55 & 1.68 \\
\hline H-54 & 2.89 & 3.54 & 5.04 \\
\hline H-55 & 1.8 & 2.08 & 4.52 \\
\hline H-56 & 3.93 & 3.8 & 4.37 \\
\hline H-57 & 4.48 & 5.37 & 4.61 \\
\hline H-58 & 4.07 & 4.1 & 3.81 \\
\hline H-59 & 3.19 & 3.46 & 4.41 \\
\hline H-60 & 6.97 & 4.79 & 8.19 \\
\hline H-61 & 4.36 & 4.26 & 4.29 \\
\hline H-62 & 3.93 & 3.65 & 7.93 \\
\hline H-63 & 2.34 & 1.84 & 1.55 \\
\hline H-64 & 1.09 & 1.25 & 1.44 \\
\hline H-65 & 1.48 & 1.48 & 1.45 \\
\hline H-66 & 0.85 & 0.92 & 0.82 \\
\hline H-67 & 1.8 & 1.27 & 0.82 \\
\hline H-68 & 0.61 & 0.68 & 0.82 \\
\hline H-69 & 1.15 & 0.95 & 0.89 \\
\hline H-70 & 0.73 & 1.12 & 0.89 \\
\hline H-71 & 0.95 & 0.74 & 0.89 \\
\hline H-72 & 2.68 & 2.51 & 1.37 \\
\hline H-73 & 1.3 & 1.3 & 1.37 \\
\hline H-74 & 1.83 & 1.94 & 1.37 \\
\hline H-75 & 5.08 & 5.34 & 8.27 \\
\hline H-76 & 3.94 & 4.38 & 4.95 \\
\hline H-77 & 1.38 & 1.39 & 1.77 \\
\hline H-78 & 1.44 & 1.38 & 2.24 \\
\hline H-79 & 6.3 & 6.29 & 6.91 \\
\hline H-80 & 1.62 & 2.08 & 1.84 \\
\hline H-81 & 2.11 & 1.6 & 2.15 \\
\hline
\end{tabular}




\begin{tabular}{|c|c|c|c|}
\hline $\mathrm{H}-82$ & 2.36 & 1.79 & 2.28 \\
\hline $\mathrm{H}-83$ & 2.76 & 3.01 & 2.53 \\
\hline $\mathrm{H}-84$ & 2.12 & 1.74 & 3.67 \\
\hline $\mathrm{H}-85$ & 1.08 & 0.99 & 1.3 \\
\hline $\mathrm{H}-86$ & 1.65 & 1.79 & 1.54 \\
\hline $\mathrm{H}-87$ & 1.3 & 1.28 & 1.19 \\
\hline $\mathrm{H}-88$ & 1.28 & 1.15 & 1.19 \\
\hline $\mathrm{H}-89$ & 1.4 & 1.13 & 1.22 \\
\hline $\mathrm{H}-90$ & 1.23 & 1.21 & 1.22 \\
\hline $\mathrm{H}-91$ & 1.23 & 1.26 & 1.23 \\
\hline $\mathrm{H}-92$ & 1.18 & 1.12 & 1.23 \\
\hline $\mathrm{H}-93$ & 1.01 & 0.95 & 0.83 \\
\hline $\mathrm{H}-94$ & 0.86 & 0.84 & 0.83 \\
\hline $\mathrm{H}-95$ & 0.88 & 0.9 & 0.83 \\
\hline $\mathrm{H}-96$ & 9.44 & 8.35 & 12 \\
\hline
\end{tabular}




\section{PGME derivatization of lydiamycin A (1)}

Lydiamycin A (1) (2 mg) was dissolved in $1 \mathrm{~mL}$ of dimethylformamide (DMF) and equal portions were transferred into two vials. The vials were treated with $5 \mathrm{mg}$ of benzotriazol-1-yloxytripyrrolidinophosphonium hexafluorophosphate (PyBOP), $2 \mathrm{mg}$ of hydroxybenzotriazole (HOBt) and $100 \mu \mathrm{L}$ of 4-methylmorpholine. $S$-PGME reagent $(5 \mathrm{mg}$ ) was added to one vial, and $R$-PGME (5 $\mathrm{mg}$ ) was added to the other. The reaction mixtures were stirred at $\mathrm{rt}$ for $1 \mathrm{~h}$, and the reactions were quenched with $5 \% \mathrm{HCl}$. After the reaction mixtures were dried in vacuo, the mixtures were purified on a reversed-phase HPLC column $\left(\mathrm{C}_{18}\right.$ Luna $10 \mu \mathrm{m} \mathrm{C}_{18}(2) 250 \times 21.2 \mathrm{~mm}, 10 \mathrm{~mL} / \mathrm{min}$, detection: $\mathrm{UV}$ at $210 \mathrm{~nm}$ ) with a gradient solvent system from $40 \%$ to $70 \% \mathrm{CH}_{3} \mathrm{CN} / \mathrm{H}_{2} \mathrm{O}$ over $40 \mathrm{~min}$. The $S$ - and $R$ PGME products (1a and $\mathbf{1 b})$ of $\mathbf{1}$ eluted at $46 \mathrm{~min}$ as white amorphous solid. The weights of reaction products were $0.7 \mathrm{mg}$ (1a, 57\% yield) and $0.8 \mathrm{mg}$ (1), $66 \%$ yield), respectively. The molecular formular of $\mathbf{1 a}$ and $\mathbf{1 b}$ were determined as $\mathrm{C}_{40} \mathrm{H}_{58} \mathrm{~N}_{8} \mathrm{O}_{10}$ by LRMS (ESI) $\left(\mathrm{m} / z\right.$ : $[\mathrm{M}+\mathrm{H}]^{+} 811$ Calcd for $\mathrm{C}_{40} \mathrm{H}_{59} \mathrm{~N}_{8} \mathrm{O}_{10}$; Found $811 /[\mathrm{M}+\mathrm{Na}]^{+} 833$ Calcd for $\mathrm{C}_{40} \mathrm{H}_{58} \mathrm{~N}_{8} \mathrm{O}_{10} \mathrm{Na}$; Found 833). The $\Delta \delta_{S-R}$ values of the products were calculated based on their ${ }^{1} \mathrm{H}$ and COSY NMR spectra data.

$S$-PGME product (1a) $(0.7 \mathrm{mg}):{ }^{1} \mathrm{H}$ NMR (DMSO- $\left.d_{6}, 800 \mathrm{MHz}\right) \delta_{\mathrm{H}} 8.67(1 \mathrm{H}, \mathrm{d}, J=7.2 \mathrm{~Hz}), 8.49(1 \mathrm{H}$, br s), $8.23(1 \mathrm{H}, \mathrm{d}, J=7.0 \mathrm{~Hz}), 8.18(1 \mathrm{H}, \mathrm{d}, J=8.8 \mathrm{~Hz}), 7.93(1 \mathrm{H}, \mathrm{d}, J=9.0 \mathrm{~Hz}), 7.39-7.33(5 \mathrm{H}, \mathrm{m})$, $6.89(1 \mathrm{H}, \mathrm{d}, J=4.2 \mathrm{~Hz}), 5.35(1 \mathrm{H}, \mathrm{d}, J=7.0 \mathrm{~Hz}), 5.04(1 \mathrm{H}, \mathrm{d}, J=5.5 \mathrm{~Hz}), 4.93(1 \mathrm{H}, \mathrm{m}), 4.60(1 \mathrm{H}, \mathrm{dd}$, $J=10.5,6.9 \mathrm{~Hz}), 4.52(1 \mathrm{H}, \mathrm{d}, J=12.5 \mathrm{~Hz}), 4.41(1 \mathrm{H}, \mathrm{dt}, J=9.3,7.2 \mathrm{~Hz}), 4.37(1 \mathrm{H}, \mathrm{dt}, J=8.5,7.5 \mathrm{~Hz})$, $4.29(1 \mathrm{H}, \mathrm{m}), 3.80(1 \mathrm{H}, \mathrm{t}, J=10.0 \mathrm{~Hz}), 3.75(1 \mathrm{H}, \mathrm{m}), 3.60(3 \mathrm{H}, \mathrm{s}), 3.02(1 \mathrm{H}, \mathrm{d}, J=12.5 \mathrm{~Hz}), 2.62(1 \mathrm{H}$, $\mathrm{m}), 2.34(1 \mathrm{H}, \mathrm{dd}, J=15.3,6.2 \mathrm{~Hz}), 2.21(1 \mathrm{H}, \mathrm{m}), 2.15-2.09(2 \mathrm{H}, \mathrm{m}), 1.84(1 \mathrm{H}, \mathrm{m}), 1.74(1 \mathrm{H}, \mathrm{m}), 1.69$ $(1 \mathrm{H}, \mathrm{m}), 1.56-1.50(2 \mathrm{H}, \mathrm{m}), 1.47-1.41(2 \mathrm{H}, \mathrm{m}), 1.37(3 \mathrm{H}, \mathrm{d}, J=7.4 \mathrm{~Hz}), 1.34(1 \mathrm{H}, \mathrm{m}), 1.27-1.17(10 \mathrm{H}$, m), $0.88(3 \mathrm{H}, \mathrm{d}, J=6.1 \mathrm{~Hz}), 0.85(3 \mathrm{H}, \mathrm{t}, J=7.0 \mathrm{~Hz}), 0.81(3 \mathrm{H}, \mathrm{d}, J=6.0 \mathrm{~Hz})$

$R$-PGME product (1b) $(0.6 \mathrm{mg}):{ }^{1} \mathrm{H}$ NMR $\left(\mathrm{DMSO}_{-}, 800 \mathrm{MHz}\right) \delta_{\mathrm{H}} 8.69(1 \mathrm{H}, \mathrm{d}, J=7.6 \mathrm{~Hz}), 8.50(2 \mathrm{H}$, br s), $8.30(1 \mathrm{H}, \mathrm{d}, J=7.0 \mathrm{~Hz}), 8.22(1 \mathrm{H}, \mathrm{d}, J=8.7 \mathrm{~Hz}), 7.93(1 \mathrm{H}, \mathrm{d}, J=8.9 \mathrm{~Hz}), 7.38-7.32(5 \mathrm{H}, \mathrm{m})$, $6.86(1 \mathrm{H}, \mathrm{d}, J=4.1 \mathrm{~Hz}), 5.40(1 \mathrm{H}, \mathrm{d}, J=7.6 \mathrm{~Hz}), 5.04(1 \mathrm{H}, \mathrm{d}, J=6.0 \mathrm{~Hz}), 4.96(1 \mathrm{H}, \mathrm{m}), 4.61(1 \mathrm{H}, \mathrm{dd}$, $J=10.6,6.8 \mathrm{~Hz}), 4.52(1 \mathrm{H}, \mathrm{d}, J=12.6 \mathrm{~Hz}), 4.42(1 \mathrm{H}, \mathrm{dt}, J=9.5,7.0 \mathrm{~Hz}), 4.37(1 \mathrm{H}, \mathrm{dt}, J=8.5,7.5 \mathrm{~Hz})$, $4.30(1 \mathrm{H}, \mathrm{m}), 3.82(1 \mathrm{H}, \mathrm{t}, J=10.0 \mathrm{~Hz}), 3.75(1 \mathrm{H}, \mathrm{m}), 3.60(3 \mathrm{H}, \mathrm{s}), 3.02(1 \mathrm{H}, \mathrm{d}, J=12.5 \mathrm{~Hz}), 2.62(1 \mathrm{H}$, m), $2.34(1 \mathrm{H}, \mathrm{dd}, J=15.1,6.5 \mathrm{~Hz}), 2.23(1 \mathrm{H}, \mathrm{m}), 2.16-2.09(2 \mathrm{H}, \mathrm{m}), 1.84(1 \mathrm{H}, \mathrm{m}), 1.77(1 \mathrm{H}, \mathrm{m}), 1.69$ $(1 \mathrm{H}, \mathrm{m}), 1.56-1.51(2 \mathrm{H}, \mathrm{m}), 1.49-1.41(4 \mathrm{H}, \mathrm{m}), 1.37(3 \mathrm{H}, \mathrm{d}, J=7.3 \mathrm{~Hz}), 1.31-1.12(12 \mathrm{H}, \mathrm{m}), 0.89(3 \mathrm{H}$, d, $J=6.2 \mathrm{~Hz}), 0.82(3 \mathrm{H}, \mathrm{d}, J=6.5 \mathrm{~Hz}), 0.81(3 \mathrm{H}, \mathrm{t}, J=7.3 \mathrm{~Hz})$ 
Figure S26. ${ }^{1} \mathrm{H}$ NMR spectrum of $S$-PGME derivatized lydiamycin A (1a) at $800 \mathrm{MHz}$ in DMSO- $d_{6}$.

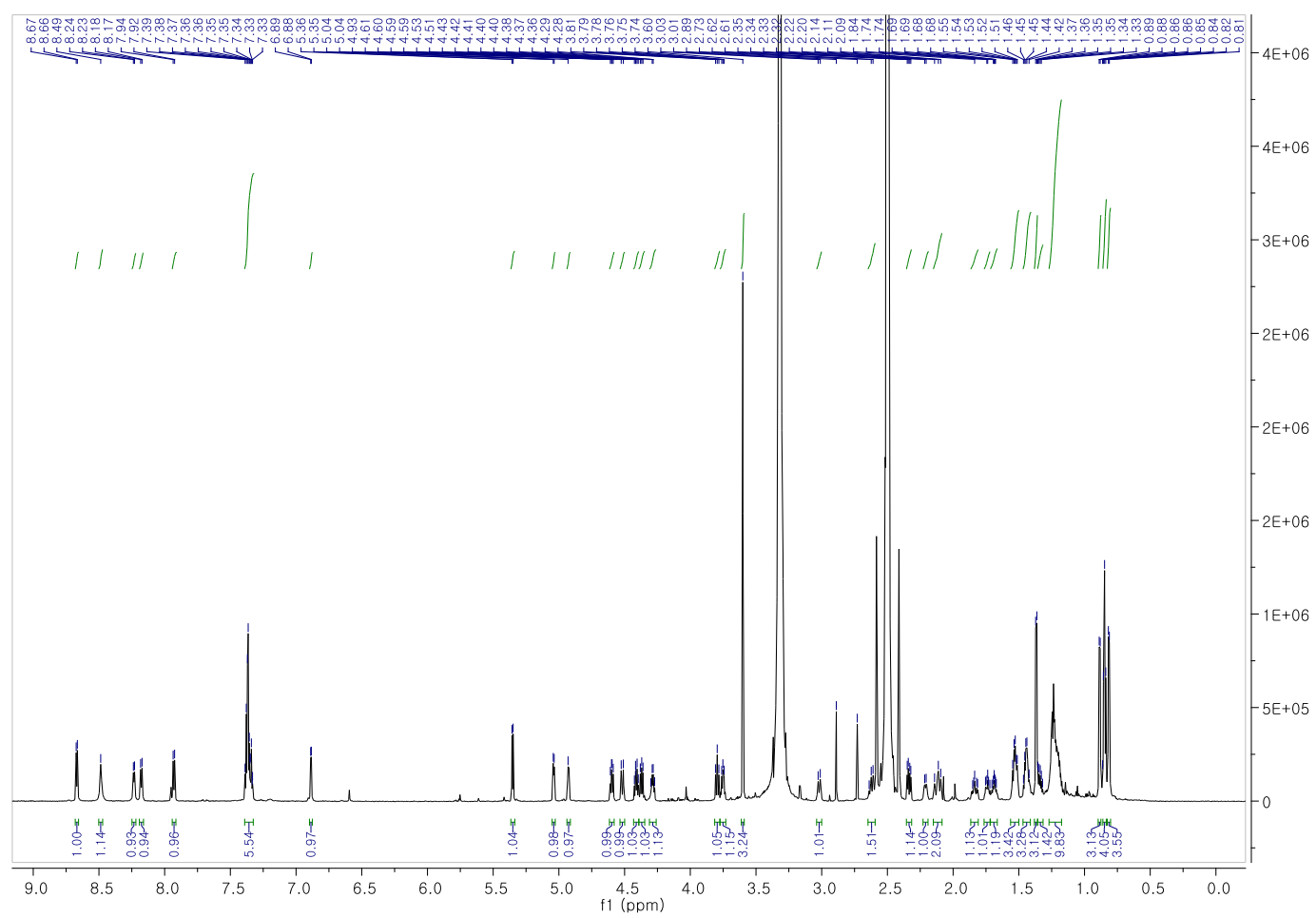

Figure S27. COSY spectrum of $S$-PGME derivatized lydiamycin A (1a) at $800 \mathrm{MHz}$ in DMSO- $d_{6}$.

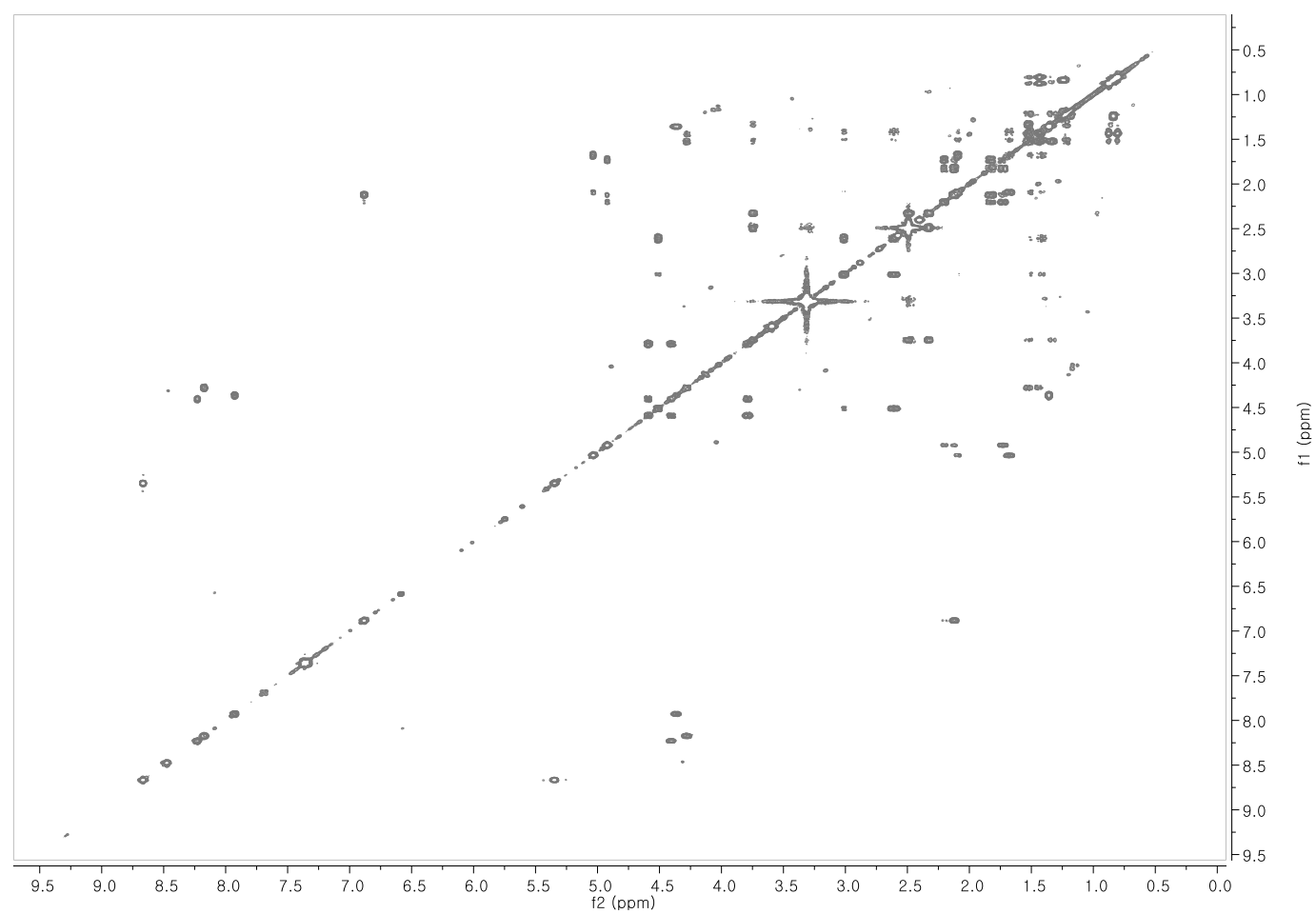


Figure S28. ${ }^{1} \mathrm{H}$ NMR spectrum of $R$-PGME derivatized lydiamycin $\mathrm{A}(\mathbf{1 b})$ at $800 \mathrm{MHz}$ in DMSO- $d_{6}$.

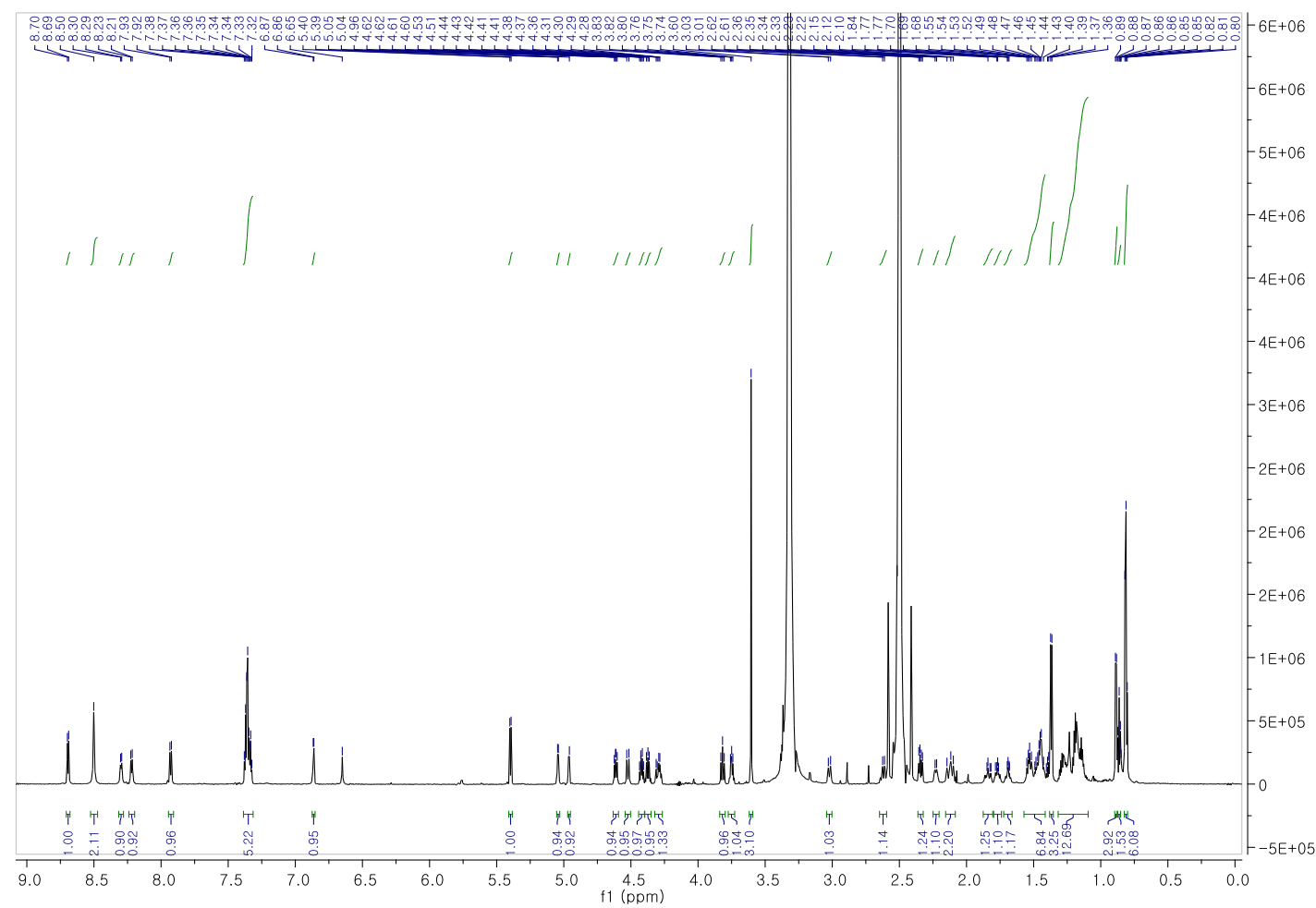

Figure S29. COSY spectrum of $S$-PGME derivatized lydiamycin A (1) at $800 \mathrm{MHz}$ in DMSO- $d_{6}$.

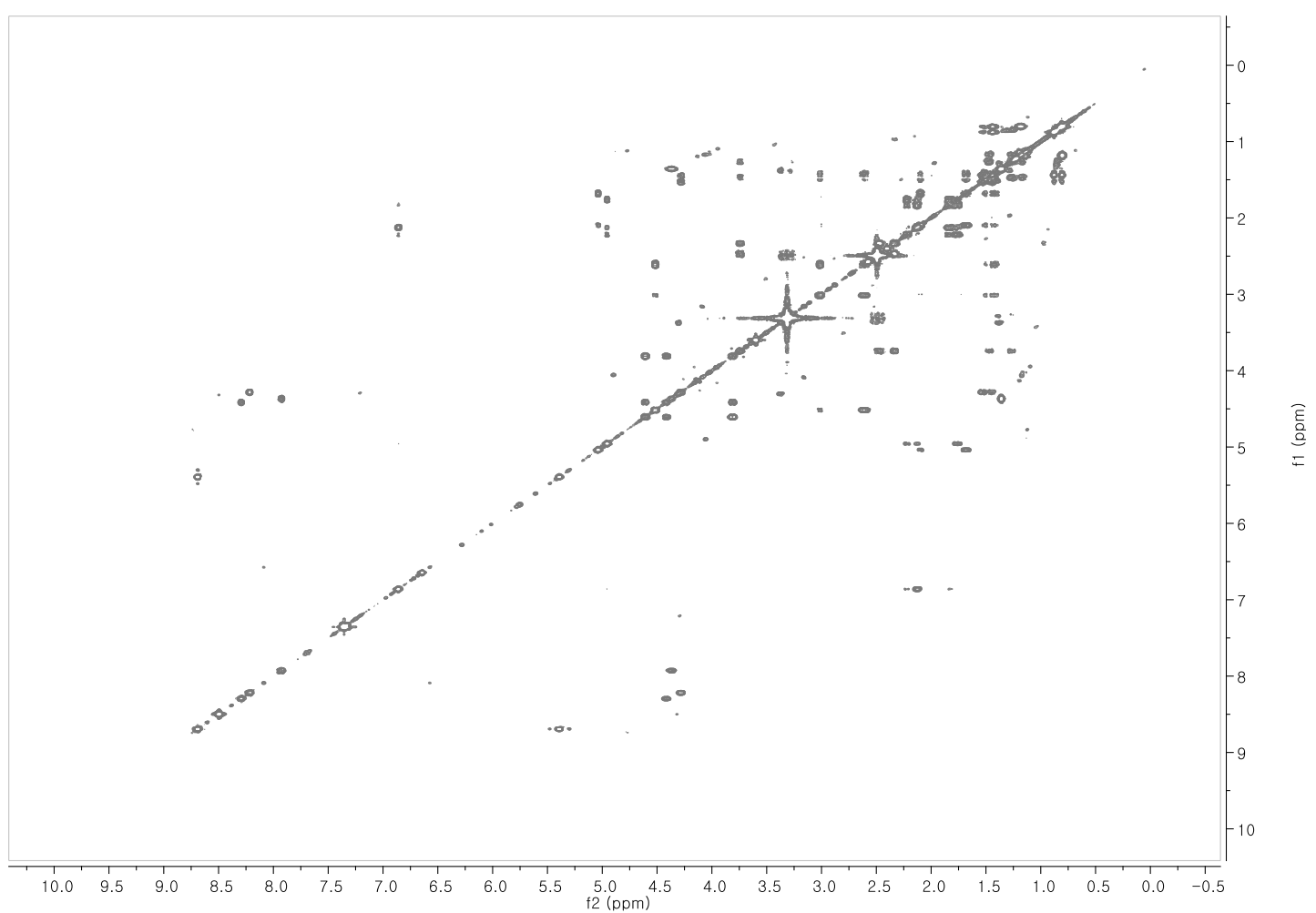


Determination of MIC value of lydiamycin A (1) for Mycobacterium tuberculosis by resazurin microtitre assay (REMA)

The MIC values of lydiamycin A (1) were determined as described previously. ${ }^{2}$ Briefly, the $M$. tuberculosis $\mathrm{mc}^{2} 6230$ strain was grown at $37^{\circ} \mathrm{C}$ in Middlebrook $7 \mathrm{H} 9$ broth containing $0.2 \%$ casamino acids and $0.24 \mu \mathrm{g} / \mathrm{mL}$ pantothenate. A $100-\mu \mathrm{L}$ aliquot of media was added to each well of a 96 -well microtiter plate, and two-fold serial dilutions of lydiamycin A (1) were carried out directly in each well. Log-phase M. tuberculosis cultures were added to each well to a final OD600 of 0.05, and the plates were incubated at $37{ }^{\circ} \mathrm{C}$ for 5 days. Resazurin $(0.025 \%$ [wt/vol]) was added to each well, and the fluorescence was measured (ex/em 560/590 nm) using a SpectraMax ${ }^{\circledR}$ M3 Multi-Mode Microplate Reader (Molecular Devices, CA, USA). The MIC values were calculated using Prism 6 (GraphPad Software, Inc., La Jolla, CA).

\section{References}

(1) Kwon, Y.; Byun, W. S.; Kim, B.-Y.; Song, M. C.; Bae, M.; Yoon, Y. J.; Shin, J.; Lee, S. K.; Oh, D.C. Molecules 2018, 23, 1266.

(2) Kim, E.; Shin, Y.-H.; Kim, T. H.; Byun, W. S.; Cui, J.; Du, Y. E.; Lim, H.-J.; Song, M. C.; Kwon, A. S.; Kang, S. H.; Shin, J.; Lee, S. K.; Jang, J.; Oh, D.-C.; Yoon, Y. J. Biomolecules 2019, 9, 672. 